\title{
Interactions of bentonite with metal and concrete from the FEBEX experiment: mineralogical and geochemical investigations of selected sampling sites
}

\author{
S. KAUFHOLD ${ }^{1, *}$, R. DOHRMANN ${ }^{1,2}, \mathrm{~K}^{*} \mathrm{UFER}^{1}$ AND F. KOBER $^{3}$ \\ BGR, Bundesanstalt für Geowissenschaften und Rohstoffe, Stilleweg 2, D-30655 Hannover, Germany \\ ${ }^{2}$ LBEG, Landesamt für Bergbau, Energie und Geologie, Stilleweg 2, D-30655 Hannover, Germany \\ ${ }^{3}$ Nagra, Nationale Genossenschaft für die Lagerung radioaktiver Abfälle, Hardstrasse 73, 5430 Wettingen, Switzerland
}

(Received 24 November 2017; revised 29 August 2018; Accepted Manuscript published online: 17 December 2018; Version of Record published online: 1 February 2019; Guest Associate Editor: M. Van Geet)

\begin{abstract}
AB S TR ACT: The FEBEX experiment, a full-scale, high-level radioactive waste repository test, ran for $\sim 18$ years and hence is the longest-running disposal test to date. The test consisted of a heater emplaced in an envelope of compacted bentonite at the Grimsel test site, Switzerland. The water content of the bentonite was somewhat lower near the heater and increased towards the granite. This phenomenon probably led to gradients in the exchangeable cation population at various locations within the bentonite buffer. The cement (shotcrete) bentonite interface of one block was characterized by a thin $(0.1-1.0 \mathrm{~mm})$ reaction zone in which bentonite constituents, carbonates and sulfates occurred. Cation exchange and a slight decrease of the cation exchange capacity were observed near the heater. Oxic corrosion was observed predominantly at the bentonite/steel liner interfaces, pointing towards a role of air entrapped between the liner and heater during emplacement. At the liner surface, intimate intergrowth of bentonite constituents, metal and corrosion products was observed. At the face of the heater, the bentonite blocks were in direct contact with the heater surface without any signs of metal corrosion. Instead, a significant increase in the Mg content was recorded, which is in agreement with previous large-scale disposal tests. The FEBEX experiment proved that the $\mathrm{Mg}$ increase and corrosion were independent processes. The increase in $\mathrm{Mg}$ may be explained by the formation of trioctahedral domains or the precipitation of neoformed silicates. For the first time, however, brucite was identified as an additional phase that formed at the metal/bentonite interface, pointing towards a special role for $\mathrm{Mg}$ mobility in the bentonite barrier.
\end{abstract}

KEYwORDS: bentonite, high-level radioactive waste repository, demonstration test, buffer material, real-scale.

This paper was presented during the " 7 th International Conference on Clays in Natural and Engineered Barriers for Radioactive Waste Confinement', September 2017. *Email: s.kaufhold@bgr.de https://doi.org/ 10.1180/clm.2018.54

This is an Open Access article, distributed under the terms of the Creative Commons Attribution licence (http:// creativecommons. org/licenses/by/4.0/), which permits unrestricted re-use, distribution, and reproduction in any medium, provided the original work is properly cited.
Large- or real-scale (full-scale) disposal tests with simulated heaters are essential for the development of suitable barrier systems for the encapsulation of highlevel radioactive waste (HLRW). They are required both to validate the safety functions and to investigate the processes taking place after closure of the repository. Worldwide, only a few heated real-scale tests have been launched: the prototype repository experiment in crystalline rock at Äspö, Sweden (Johannesson et al., 2007; Dohrmann \& Kaufhold, 
2014; Svemar et al., 2016), the PRACLAY experiment in Boom Clay at the HADES rock laboratory in Belgium (Bernier et al., 2007), the ALC (full-scale demonstrations experiment at Bure URL) experiment in Callovo-Oxfordian Clay at ANDRA's rock laboratory in France (Gugala, 2015), the recently installed FE experiment (full-scale emplacement experiment) in Opalinus Clay at Mont Terri in Switzerland (Müller et al., 2017) and the FEBEX test investigated in the present study.

Previous large and full-scale experiments demonstrated that corrosion, mineral dissolution and precipitation, $\mathrm{Mg}$ enrichment at the heater and cation exchange occur across the whole bentonite barrier. The cation exchange capacity (CEC) is probably the most important parameter for evaluating the performance of a barrier in crystalline rocks because it reflects the swelling capacity of the bentonite and may be determined with comparatively high precision. Most dissolution/precipitation reactions (involving e.g. carbonates, sulfates, selected silicates) and cation exchange may be explained based on geochemical modelling (Arcos et al., 2000; Wallis et al., 2015). The mechanisms behind corrosion and $\mathrm{Mg}$ enrichment, in contrast, are still under discussion (Kaufhold et al., 2015, 2016). The $\mathrm{Mg}$ enrichment is particularly interesting because the possible Mg source (incongruent smectite dissolution and/or cation exchange) is related to the chemical stability of smectite, and the type of alteration product (saponitic smectite, brucite or other Mg-silicates) determines the local performance (e.g. swelling capacity) of the barrier.

The 'full-scale engineered buffer experiment' (FEBEX) was the first full-scale test of a horizontal disposal system for HLRW (Lanyon \& Gaus, 2015). It consisted of two heaters embedded in compacted bentonite blocks. The heater of the FEBEX experiment started operating in 1997. The first parts of the experiment were removed in 2002 (partial dismantling; Huertas et al., 2006). Details about the experiments have been summarized previously (e.g. Fernández et al., 2001; Lanyon \& Gaus, 2013; Fernández, 2017; Garralón et al., 2017). The second heater was dismantled in 2015 (García-Siñeriz et al., 2016) after 18 years of operation at $100^{\circ} \mathrm{C}$. A full monitoring account of the FEBEX experiment was compiled by Martinez et al. (2016).

The varying performance of bentonite samples retrieved from part 1 of the FEBEX test may be explained by the various hydration and temperature gradients in the bentonite in contact with the granite (Huertas et al., 2006; Villar et al., 2006; Lloret
\& Villar, 2007; Villar \& Lloret, 2007). The investigation of the proceeding hydration, therefore, was of particular interest in the second part of the project. The aim of the present study is to investigate the cation exchange reactions and the geochemical and mineralogical reactions taking place at various interfaces and selected sampling sites and finally to identify the geochemical and mineralogical changes to the bentonite caused by the heater and inflowing water over 18 years of operation.

\section{MATERIALS AND METHODS}

\section{Samples}

Samples were taken from various sections of the FEBEX experiment, focusing on interfaces (e.g. cement/shotcrete-bentonite, iron-bentonite; GarcíaSiñeriz et al., 2016). The cement/shotcrete was characterized by Huertas et al. (2006). In addition, four radial profiles in the bentonite buffer were sampled without interfaces. The samples were drilled either from blocks from interfaces or from cores (Fig. 1). Interface samples were collected by scratching off the surface with a sharp knife. The samples were sealed in aluminium foil. In addition, some specific samples were collected (Fig. 2) from macroscopically interesting sample sites (black material from liner surface, reddish clay in the holes of the liner).

\section{Methods}

The geochemical composition of the samples was determined by wavelength-dispersive X-ray fluorescence spectroscopy (XRF), elemental C- and Sanalysis (LECO, USA) and CEC including exchangeable cations (ECs). Selected samples were also analysed by X-ray diffraction (XRD), scanning electron microscopy (SEM), infrared (IR) spectroscopy and simultaneous thermal analysis (STA) coupled with a mass spectrometer (MS) to study the composition of the evolved gas.

For XRF analysis of powdered samples, a PANalytical Axios spectrometer was used (ALMELO, The Netherlands). Samples were prepared by mixing with lithium metaborate (Spectroflux, Flux No. 100A, Alfa Aesar) and melting into glass beads. The loss on ignition (LOI) of the samples was determined by heating $1000 \mathrm{mg}$ of the materials at $1030^{\circ} \mathrm{C}$ for $10 \mathrm{~min}$.

The total organic carbon (TOC) content was determined with a LECO CS-444 analyser after dissolution of the carbonates. Carbonates were removed by treating the samples several times at 


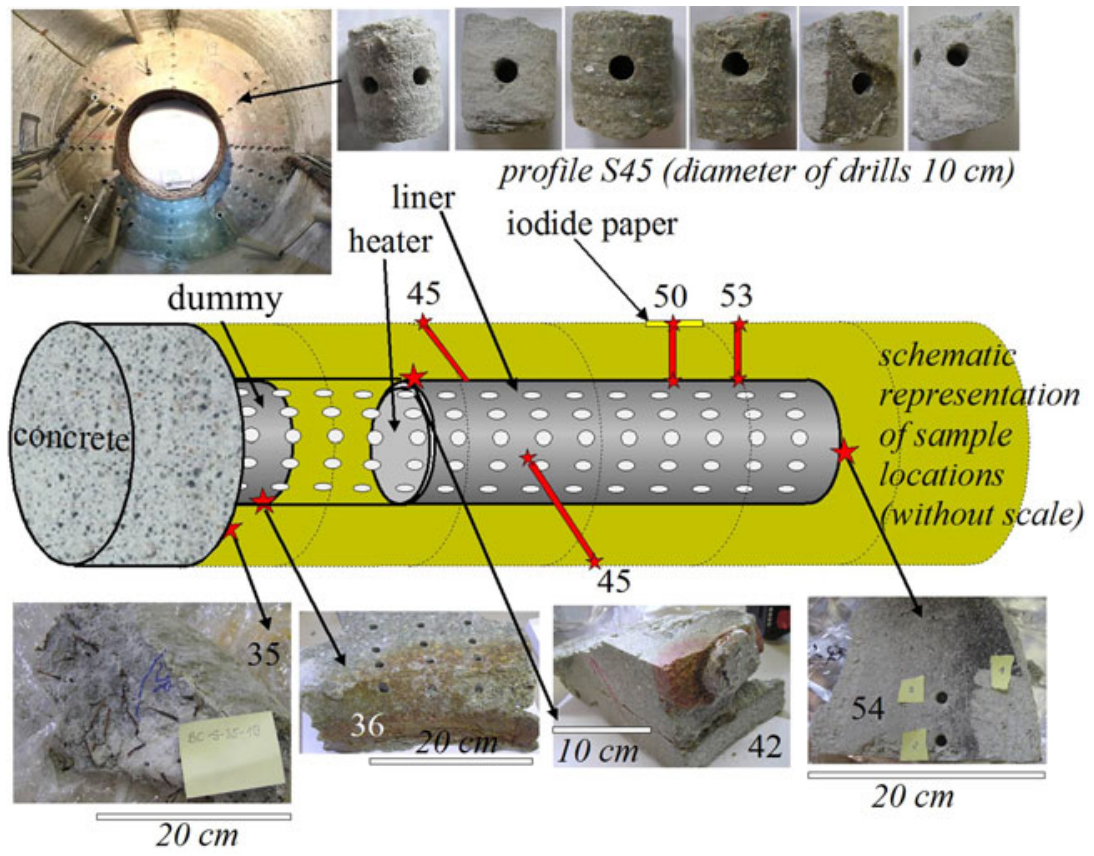

FIG. 1. Schematic representation of sample locations (various interfaces and four profiles). For a full dismantling and sampling layout, see García-Siñeriz et al. (2016).

$80^{\circ} \mathrm{C}$ with $\mathrm{HCl}$ until no further gas evolution was observed. Aliquots of $170-180 \mathrm{mg}$ of the dried materials were used to measure the total carbon (TC) content. Total inorganic carbon (TIC) was calculated as the difference between TC and TOC. The samples were heated in the device to $1800-2000^{\circ} \mathrm{C}$ in an oxygen atmosphere (LECO 3000) and the $\mathrm{CO}_{2}$ was detected by an IR detector.

The CEC was measured using the Cu-triethylenetetramine (Cu-trien) method (Meier \& Kahr, 1999).

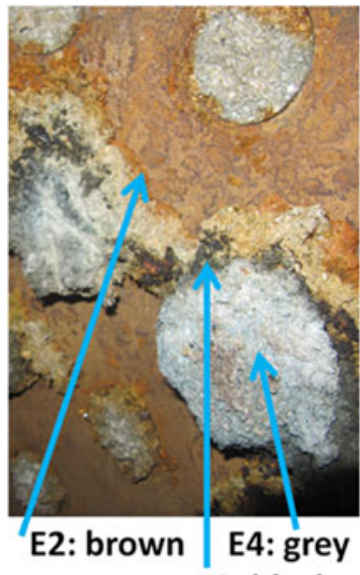

E3: black
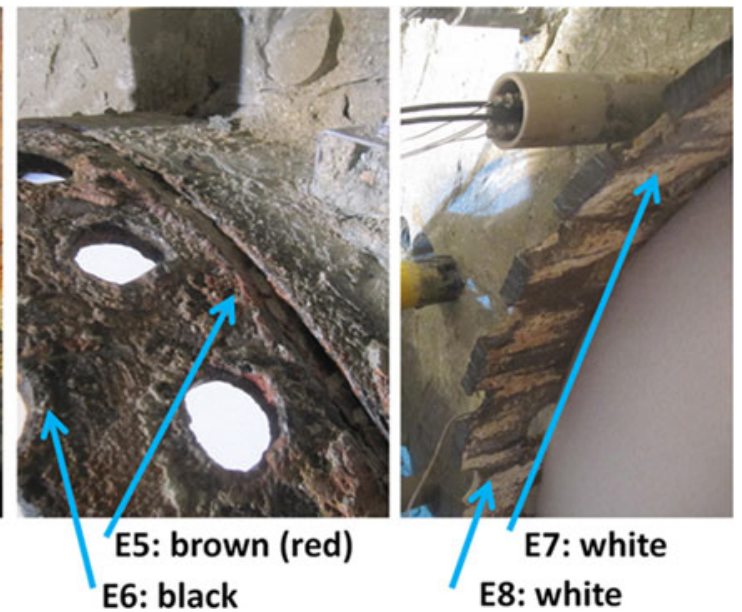

E8: white

FIG. 2. Sampling of special interfaces of the FEBEX experiment. These samples were not official FEBEX samples, but were taken from surfaces that had undergone geochemical reactions according to visual inspection. Samples were collected according to the colours observed in the field. $\mathrm{E}=$ extra. 
The FEBEX samples were analysed using $30 \mathrm{~mL} \mathrm{Cu}$ trien solution and no additional water. Two different sample masses were analysed and average values were calculated. After $\mathrm{Cu}$-trien saturation, the solutions were centrifuged to sediment the bentonites, and the supernatant solutions were diluted and analysed using inductively coupled plasma-optical emission spectrometry (ICP-OES; Thermo Scientific ICAP 6300 DUO ICP-OES, Thermo Fisher Scientific, USA) to measure the ECs and $\mathrm{Cu}$ for the calculation of CEC values. For ICP-OES analysis, the following parameters were used: argon radial plasma, nebulizers (cross-flow and modified Lichte), no auxiliary gas flow, gain value for plasma $(1.400 \mathrm{~W})$ and calibration every seventh measurement. The Cu-trien complex concentration was also analysed using visible (VIS) spectroscopy (Jenway 6200, Cole-Parmer, UK) to cross-check the ICP-Cu concentration. Each CEC value was calculated by averaging four single CEC values (two from ICP analysis and two from VIS spectroscopy). Each EC value was calculated by averaging only two single EC values measured using ICP. The error $( \pm 3 \sigma)$ in values determined using the Cu-trien ${ }_{5 \times \text { calcite }}$ method for bentonites (Dohrmann \& Kaufhold, 2009) is different for various cations and the CEC. The scattering is lowest for $\mathrm{K}^{+}( \pm 0.3 \mathrm{meq} / 100 \mathrm{~g})$, followed by $\mathrm{Mg}^{2+}( \pm 0.8 \mathrm{meq} / 100 \mathrm{~g}), \mathrm{Ca}^{2+}( \pm 0.8 \mathrm{meq} /$ $100 \mathrm{~g}), \mathrm{Na}^{+}( \pm 1.9 \mathrm{meq} / 100 \mathrm{~g})$ and the total CEC $( \pm 3.1$ $\mathrm{meq} / 100 \mathrm{~g}$ ). These values may be used to evaluate approximately the accuracy in this study.

The XRD powder traces of the samples were recorded with a PANalytical X'Pert PRO MPD $\theta-\theta$ diffractometer (Co- $K \alpha$ radiation generated at $40 \mathrm{kV}$ and $40 \mathrm{~mA}$ ), equipped with a variable divergence slit (20 mm irradiated length), primary and secondary Soller, diffracted beam monochromator, point detector and a sample changer (sample diameter $28 \mathrm{~mm}$ ). The samples were investigated from $1^{\circ}$ to $80^{\circ} 2 \theta$ with a step size of $0.03^{\circ} 2 \theta$ and a measuring time of $5 \mathrm{~s}$ per step. For specimen preparation, the back-loading technique was used. The XRD traces were used for Rietveld refinement with the $B G M N$ code. Refinements were performed according to Ufer et al. (2008).

Oriented XRD mounts (texture slide XRD) were prepared using $15 \mathrm{mg} / \mathrm{cm}^{2}$ clay. An aliquot of $1.5 \mathrm{~mL}$ of suspension was deposited on circular (diameter $=$ $2.4 \mathrm{~cm}) 3 \mathrm{~mm}$-thick ceramic tiles. The suspensions were filtered through the tile using a vacuum filter apparatus. X-ray diffraction patterns of the oriented mounts were recorded with the same diffractometer as the bulk powder samples The air-dried and ethylene glycol (EG)-solvated $\left(60^{\circ} \mathrm{C}\right.$ overnight) samples were investigated from $1^{\circ}$ to $40^{\circ} 2 \theta$ with a step size of $0.03^{\circ}$ $2 \theta$ and a counting time of $6 \mathrm{~s}$ per step.

For SEM investigation, a FEI Quanta $600 \mathrm{~F}$ scanning electron microscope operated in lowvacuum mode ( $0.6 \mathrm{mbar}$ ) was used, without prior sputtering of the samples with gold or carbon. The microscope was equipped with the EDX system Genesis 4000 of EDAX. A freshly broken surface of the unprocessed air-dried sample was fixed on a carbon grid and used for SEM inspection.

Mid-IR (MIR) spectra of the samples were obtained with the $\mathrm{KBr}$ pellet technique (1 mg sample/200 mg $\mathrm{KBr}$ ). Spectra were collected on a Thermo Nicolet Nexus (USA) Fourier-transform IR spectrometer (MIR beam splitter: $\mathrm{KBr}$ detector DTGS TEC; deuterated triglycine sulfate detector and thermoelectricity cooled) with a resolution of $2 \mathrm{~cm}^{-1}$. Measurements were conducted before and after drying of the pellets at $150^{\circ} \mathrm{C}$ in a vacuum oven for $24 \mathrm{~h}$.

Simultaneous thermal analyses were performed with a Netzsch 449 F3 Jupiter thermobalance (Germany) equipped with a DSC/TG (differential scanning calorimetry/thermal gravimetry) sample holder linked to a Netzsch QMS 403 C Aeolus MS. A total of $100 \mathrm{mg}$ of powdered material previously equilibrated at $53 \%$ relative humidity $(\mathrm{RH})$ was heated from 25 to $1150^{\circ} \mathrm{C}$ with a heating rate of $10^{\circ} \mathrm{C} / \mathrm{min}$.

The water content was determined gravimetrically after drying for 1 week at $60^{\circ} \mathrm{C}$.

\section{RESULTS AND DISCUSSION}

\section{Database and reference}

All results that are discussed below are summarized in Tables 1 and 2. Geochemical and mineralogical changes of the bentonite caused by the heater and inflowing water over 18 years of operation may be identified only if reliable reference data of the bentonite before the experiment are available. Most of the changes identified in other large-scale tests, however, were restricted to the contacts with the hot metal or with the cement (Dohrmann et al., 2013, 2017; Kaufhold et al., 2013, 2017). Therefore, reference data may also be obtained from material derived from the centre of the blocks taken at a distance from the interfaces. For such samples, however, cation exchange has to be taken into account.

For the present study, none of the originally used bentonite was available as a reference material. Therefore, the FEBEX bentonite used for the ABM test (Alternative Buffer Materials; Dohrmann et al., 
TABLE 1. Mineralogical and chemical characterization of the interfaces sampled for the present study.

\begin{tabular}{|c|c|c|c|c|c|c|c|c|c|c|c|c|c|c|c|c|c|c|c|}
\hline & $\begin{array}{l}\text { REF } \\
\text { ABM }\end{array}$ & $\begin{array}{l}\text { REF } \\
\text { averg.22 }\end{array}$ & $\begin{array}{l}\text { BC-S- } \\
35-1 \mathrm{a}\end{array}$ & $\begin{array}{l}\text { BC- } \\
\text { S-35- } \\
\text { la }\end{array}$ & $\begin{array}{l}\text { BC-S- } \\
35-1 b\end{array}$ & $\begin{array}{l}\text { BC-S- } \\
35-1 b\end{array}$ & $\begin{array}{l}\text { B-S-36- } \\
31 \mathrm{~mm}\end{array}$ & $\begin{array}{l}\text { BM-S- } \\
42-1 \\
(2)\end{array}$ & $\begin{array}{l}\text { BM-S- } \\
42-2\end{array}$ & $\begin{array}{l}\text { BM-S- } \\
42-2 \mathrm{a} \\
+\mathrm{b}\end{array}$ & E2 & E3 & E4 & E5 & E6 & E7 & E8 & $\begin{array}{l}\text { BM- } \\
\text { S-54- } \\
\text { 5B 1 }\end{array}$ & $\begin{array}{l}\text { BM-S- } \\
54-5 \mathrm{C} \\
3\end{array}$ \\
\hline Distance $(\mathrm{cm})$ & \multirow{2}{*}{\multicolumn{2}{|c|}{ References }} & 0.1 & 1.0 & 0.1 & 1.0 & 0.1 & 0.1 & 0.1 & 1.0 & \multirow{2}{*}{\multicolumn{7}{|c|}{ Corrosion }} & 0.1 & 0.1 \\
\hline Topic & & & & & ement & & & & & & & & & & & & & \multicolumn{2}{|c|}{$\mathrm{MgO}$ increase } \\
\hline \multicolumn{20}{|l|}{$\begin{array}{l}\text { XRD Rietveld } \\
\text { (mass\%) }\end{array}$} \\
\hline Quartz & 1 & & 5 & & 3 & & 2 & & 1 & 2 & 2 & 1 & 2 & 2 & 2 & 1 & & 2 & 2 \\
\hline K-fsp & 5 & & 3 & & 4 & & 4 & & 4 & 4 & 4 & 5 & 4 & 4 & & 4 & & 2 & 4 \\
\hline Smectite & 84 & & 79 & & 83 & & 82 & & 83 & 84 & 83 & 84 & 86 & 81 & 52 & 55 & & 87 & 86 \\
\hline Plagioclase & 9 & & 10 & & 8 & & 10 & & 9 & 9 & 8 & 10 & 8 & 8 & 9 & 5 & & 6 & 8 \\
\hline Calcite & 1 & & 1 & & 2 & & 0 & & 0 & 0 & 0 & 0 & 1 & 0 & & 2 & & 0 & 1 \\
\hline Goethite & & & & & & & 2 & & 2 & 1 & 3 & & & 5 & 4 & & & & \\
\hline $\begin{array}{c}\text { Kaolinite/ } \\
\text { brucite }\end{array}$ & & & $2^{\mathrm{a}}$ & & $0^{\mathrm{a}}$ & & & & & & & & & & & & & 2 & \\
\hline Siderite & & & & & & & & & & & & & & & 7 & & & & \\
\hline $\begin{array}{l}\text { Magnetite/ } \\
\text { maghemite }\end{array}$ & & & & & & & & & & & & & & & 18 & & & & \\
\hline Iron & & & & & & & & & & & & & & & 0 & & & & \\
\hline Muscovite & & & & & & & & & & & & & & & 7 & & & & \\
\hline Aragonite & & & & & & & & & & & & & & & & 30 & & & \\
\hline Dolomite & & & & & & & & & & & & & & & & 2 & & & \\
\hline \multicolumn{20}{|l|}{$\begin{array}{l}\text { CEC method } \\
\text { (meq } / 100 \mathrm{~g})\end{array}$} \\
\hline $\mathrm{Na}^{+}$ & 27 & 28 & 17 & 28 & 21 & 27 & 24 & 26 & 25 & 26 & 27 & 31 & 24 & 25 & 9 & 16 & 17 & 16 & 20 \\
\hline $\mathrm{K}^{+}$ & 3 & 3 & 3 & 5 & 4 & 4 & 4 & 3 & 2 & 2 & 3 & 3 & 3 & 3 & 1 & 2 & 2 & 3 & 3 \\
\hline $\mathrm{Mg}^{2+}$ & 38 & 36 & 33 & 22 & 28 & 26 & 36 & 37 & 36 & 37 & 38 & 33 & 54 & 36 & 16 & 25 & 28 & 40 & 44 \\
\hline $\mathrm{Ca}^{2+}$ & 40 & 41 & $18^{\mathrm{a}}$ & 44 & 49 & 45 & 39 & 41 & 37 & 38 & 41 & 44 & 54 & 37 & 32 & 29 & 32 & 36 & 51 \\
\hline Sum & 108 & 107 & 72 & 99 & 102 & 103 & 103 & 106 & 101 & 103 & 110 & 111 & 135 & 101 & 59 & 72 & 79 & 95 & 119 \\
\hline $\mathrm{CEC}$ & 98 & 98 & $56^{\mathrm{a}}$ & 90 & $77^{\mathrm{a}}$ & 94 & 90 & 97 & 95 & 97 & 91 & 87 & 91 & 93 & 38 & 54 & 60 & 64 & 83 \\
\hline
\end{tabular}


TABLE 1. (contd.)

\begin{tabular}{|c|c|c|c|c|c|c|c|c|c|c|c|c|c|c|c|c|c|c|c|}
\hline & $\begin{array}{l}\text { REF } \\
\text { ABM }\end{array}$ & $\begin{array}{l}\text { REF } \\
\text { averg.22 }\end{array}$ & $\begin{array}{l}\text { BC-S- } \\
35-1 \mathrm{a}\end{array}$ & $\begin{array}{l}\text { BC- } \\
\text { S-35- } \\
\text { 1a }\end{array}$ & $\begin{array}{l}\text { BC-S- } \\
35-1 b\end{array}$ & $\begin{array}{l}\text { BC-S- } \\
35-1 b\end{array}$ & $\begin{array}{l}\text { B-S-36- } \\
31 \mathrm{~mm}\end{array}$ & $\begin{array}{l}\text { BM-S- } \\
42-1 \\
(2)\end{array}$ & $\begin{array}{l}\text { BM-S- } \\
42-2\end{array}$ & $\begin{array}{l}\text { BM-S- } \\
42-2 \text { a } \\
+b\end{array}$ & E2 & E3 & $\mathrm{E} 4$ & E5 & E6 & E7 & E8 & $\begin{array}{l}\text { BM- } \\
\text { S-54- } \\
\text { 5B } 1\end{array}$ & $\begin{array}{l}\text { BM-S- } \\
54-5 \mathrm{C} \\
3\end{array}$ \\
\hline \multicolumn{20}{|c|}{$X R F$ (mass\%) } \\
\hline $\mathrm{SiO}_{2}$ & 55.2 & 54.8 & 50.5 & 54.5 & 51.5 & 55.0 & 52.5 & 53.4 & 53.2 & 54.9 & 50.3 & 52.4 & 52.7 & 52.7 & 29.6 & 33.0 & 38.4 & 50.4 & 52.0 \\
\hline $\mathrm{TiO}_{2}$ & 0.2 & 0.2 & 0.2 & 0.2 & 0.2 & 0.2 & 0.2 & 0.2 & 0.2 & 0.2 & 0.2 & 0.2 & 0.2 & 0.2 & 0.1 & 0.1 & 0.2 & 0.2 & 0.2 \\
\hline $\mathrm{Al}_{2} \mathrm{O}_{3}$ & 17.2 & 17.2 & 15.2 & 16.9 & 15.9 & 17.3 & 16.3 & 16.8 & 16.8 & 17.1 & 16.7 & 15.8 & 16.8 & 16.5 & 9.3 & 10.4 & 12.0 & 15.5 & 16.3 \\
\hline $\mathrm{Fe}_{2} \mathrm{O}_{3}$ & 3.1 & 3.3 & 3.1 & 3.2 & 2.9 & 3.3 & $7.3^{\mathrm{a}}$ & 4.8 & $6.7^{\mathrm{a}}$ & 4.6 & 8.5 & 6.2 & 3.2 & 7.8 & 37.1 & 4.1 & 2.8 & 3.2 & 2.9 \\
\hline $\mathrm{MnO}$ & 0.0 & 0.0 & 0.1 & 0.0 & 0.1 & 0.0 & 0.0 & 0.1 & 0.0 & 0.0 & 0.0 & 0.0 & 0.1 & 0.0 & 0.5 & 0.2 & 0.1 & 0.1 & 0.1 \\
\hline $\mathrm{MgO}$ & 4.4 & 4.4 & $10.8^{\mathrm{a}}$ & 4.7 & $7.5^{\mathrm{a}}$ & 4.4 & 4.2 & 4.9 & 4.3 & 4.3 & 4.3 & 4.3 & 5.9 & 4.2 & 3.1 & 5.1 & 4.1 & 10.1 & 6.9 \\
\hline $\mathrm{CaO}$ & 1.8 & 1.9 & 2.1 & 2.4 & 2.9 & 2.2 & 1.7 & 1.7 & 1.5 & 1.5 & 1.5 & 1.9 & 2.0 & 1.4 & 3.1 & 18.5 & 15.9 & 2.1 & 2.2 \\
\hline $\mathrm{Na}_{2} \mathrm{O}$ & 1.1 & 1.1 & 1.1 & 1.3 & 1.0 & 1.2 & 1.1 & 1.1 & 1.1 & 1.1 & 1.1 & 1.3 & 1.0 & 1.1 & 0.5 & 0.8 & 0.8 & 0.8 & 0.9 \\
\hline $\mathrm{K}_{2} \mathrm{O}$ & 1.0 & 1.0 & 1.1 & 1.1 & 1.0 & 1.2 & 1.0 & 0.8 & 0.9 & 1.0 & 0.9 & 0.9 & 0.9 & 0.9 & 0.5 & 0.6 & 0.7 & 0.9 & 0.9 \\
\hline $\mathrm{P}_{2} \mathrm{O}_{5}$ & 0.0 & 0.0 & 0.0 & 0.0 & 0.0 & 0.0 & 0.0 & 0.0 & 0.0 & 0.0 & 0.0 & 0.0 & 0.0 & 0.0 & 0.0 & 0.0 & 0.0 & 0.0 & 0.0 \\
\hline $\mathrm{SO}_{3}$ & 0.1 & 0.0 & 0.1 & 0.0 & 0.5 & 0.0 & 0.1 & 0.0 & 0.0 & 0.0 & $<0.01$ & $<0.01$ & 0.1 & 0.0 & 0.1 & 0.1 & 0.1 & 0.0 & 0.0 \\
\hline LOI & 16.0 & 15.7 & 15.5 & 15.5 & 16.4 & 15.0 & 15.6 & 16.1 & 15.1 & 15.1 & 16.3 & 16.8 & 17.1 & 15.1 & 15.9 & 27.0 & 24.6 & 16.6 & 17.5 \\
\hline Sum & 100.0 & 99.9 & 99.9 & 99.9 & 99.9 & 99.9 & 99.9 & 99.8 & 99.9 & 99.9 & 99.9 & 99.9 & 99.9 & 99.9 & 99.6 & 99.7 & 99.7 & 99.9 & 99.9 \\
\hline \multicolumn{20}{|c|}{$\begin{array}{c}\text { LECO (mass } \\
\% \text { ) }\end{array}$} \\
\hline $\mathrm{C}_{\text {total }}$ & 0.1 & 0.1 & $0.4^{\mathrm{a}}$ & 0.3 & $0.4^{\mathrm{a}}$ & 0.2 & 0.2 & 0.1 & 0.1 & 0.1 & 0.1 & 0.1 & 0.1 & 0.1 & 1.6 & 4.4 & 3.3 & 0.3 & 0.2 \\
\hline $\mathrm{C}_{\text {org }}$ & 0.0 & 0.1 & 0.1 & 0.1 & 0.1 & 0.1 & 0.1 & 0.1 & 0.1 & 0.1 & 0.1 & 0.1 & 0.1 & 0.1 & 0.1 & 0.1 & 0.2 & 0.1 & 0.1 \\
\hline $\mathrm{C}_{\text {carb }}$ & 0.1 & 0.1 & $0.3^{\mathrm{a}}$ & 0.2 & $0.3^{\mathrm{a}}$ & 0.1 & 0.1 & 0.1 & 0.0 & 0.0 & 0.0 & 0.0 & 0.1 & 0.0 & 1.5 & 4.3 & 3.2 & 0.2 & 0.1 \\
\hline $\mathrm{S}_{\text {total }}$ & 0.0 & 0.0 & 0.1 & 0.0 & 0.2 & 0.0 & 0.0 & 0.0 & 0.0 & 0.0 & 0.0 & 0.0 & 0.1 & 0.0 & 0.1 & 0.1 & 0.1 & 0.0 & 0.0 \\
\hline
\end{tabular}

0.0 means $<0.5$ mass $\%$ (few but present).

${ }^{a}$ Significant changes of the parameter compared to initial values. These are discussed in the text. 
TABLE 2. Geochemical data of the four profiles (sections 45 [two profiles], 50, 53) investigated in the present study.

\begin{tabular}{|c|c|c|c|c|c|c|c|c|c|c|c|c|c|c|c|c|}
\hline & $\begin{array}{l}\text { REF } \\
\text { ABM }\end{array}$ & $\begin{array}{c}\text { REF } \\
\text { averg.22 }\end{array}$ & $\begin{array}{l}\text { B-C- } \\
45-23\end{array}$ & $\begin{array}{l}\text { B-C- } \\
45-24\end{array}$ & $\begin{array}{l}\text { B-C- } \\
45-25\end{array}$ & $\begin{array}{l}\text { B-C- } \\
45-26\end{array}$ & $\begin{array}{l}\text { B-C- } \\
45-27\end{array}$ & $\begin{array}{l}\text { B-C- } \\
45-28\end{array}$ & $\begin{array}{l}\text { B-C- } \\
45-29\end{array}$ & $\begin{array}{l}\text { B-C- } \\
45-48\end{array}$ & $\begin{array}{l}\text { B-C- } \\
45-49\end{array}$ & $\begin{array}{l}\text { B-C- } \\
45-50\end{array}$ & $\begin{array}{l}\text { B-C- } \\
45-51\end{array}$ & $\begin{array}{l}\text { B-C- } \\
45-52\end{array}$ & $\begin{array}{l}\text { B-C- } \\
45-53\end{array}$ & $\begin{array}{l}\text { B-C- } \\
45-54\end{array}$ \\
\hline $\begin{array}{l}\text { Distance }(\mathrm{cm}) \\
\text { Topic }\end{array}$ & \multicolumn{2}{|c|}{ References } & \multicolumn{14}{|c|}{ Section 45} \\
\hline \multicolumn{17}{|c|}{$C E C_{C u \text {-trien }}(\mathrm{meg} / 100 \mathrm{~g})$} \\
\hline $\mathrm{Na}^{+}$ & 27 & 28 & 29 & 29 & 29 & 28 & 28 & 26 & 23 & 28 & 29 & 28 & 28 & 26 & 27 & 22 \\
\hline $\mathrm{K}^{+}$ & 3 & 3 & 2 & 3 & 3 & 3 & 2 & 3 & 3 & 2 & 3 & 3 & 3 & 3 & 3 & 3 \\
\hline $\mathrm{Mg}^{2+}$ & 38 & 36 & 36 & 35 & 34 & 34 & 34 & 36 & 48 & 35 & 34 & 34 & 34 & 35 & 38 & 47 \\
\hline $\mathrm{Ca}^{2+}$ & 40 & 41 & 39 & 42 & 41 & 43 & 43 & 44 & 48 & 38 & 42 & 44 & 43 & 41 & 46 & 45 \\
\hline Sum & 108 & 107 & 107 & 110 & 106 & 108 & 108 & 110 & 122 & 104 & 107 & 109 & 108 & 105 & 114 & 117 \\
\hline CEC & 98 & 98 & 102 & 103 & 100 & 100 & 99 & 101 & 101 & 98 & 98 & 99 & 99 & 97 & 102 & 97 \\
\hline \multicolumn{17}{|l|}{$X R F(\operatorname{mass} \%)$} \\
\hline $\mathrm{SiO}_{2}$ & 55.2 & 54.8 & 54.1 & 53.8 & 54.4 & 54.2 & 54.2 & 54.7 & 53.8 & 54.2 & 53.8 & 53.0 & 54.4 & 54.7 & 54.1 & 54.3 \\
\hline $\mathrm{TiO}_{2}$ & 0.2 & 0.2 & 0.2 & 0.2 & 0.2 & 0.2 & 0.2 & 0.2 & 0.2 & 0.2 & 0.2 & 0.2 & 0.2 & 0.2 & 0.2 & 0.2 \\
\hline $\mathrm{Al}_{2} \mathrm{O}_{3}$ & 17.2 & 17.2 & 17.2 & 17.0 & 17.1 & 17.1 & 17.0 & 16.9 & 16.9 & 17.2 & 16.9 & 16.6 & 16.9 & 16.8 & 17.0 & 16.6 \\
\hline $\mathrm{Fe}_{2} \mathrm{O}_{3}$ & 3.1 & 3.3 & 3.1 & 3.1 & 3.1 & 3.3 & 3.4 & 3.1 & 3.1 & 3.1 & 3.1 & 3.0 & 3.1 & 3.1 & 3.2 & 3.1 \\
\hline $\mathrm{MnO}$ & 0.0 & 0.0 & 0.0 & 0.0 & 0.0 & 0.0 & 0.0 & 0.0 & 0.0 & 0.0 & 0.0 & 0.0 & 0.0 & 0.0 & 0.0 & 0.0 \\
\hline $\mathrm{MgO}$ & 4.4 & 4.4 & 4.3 & 4.3 & 4.2 & 4.3 & 4.3 & 4.3 & 4.5 & 4.2 & 4.2 & 4.3 & 4.2 & 4.3 & 4.3 & 4.6 \\
\hline $\mathrm{CaO}$ & 1.8 & 1.9 & 1.7 & 1.9 & 1.7 & 2.0 & 1.8 & 1.8 & 1.8 & 1.8 & 2.1 & 2.9 & 1.9 & 1.6 & 1.8 & 1.7 \\
\hline $\mathrm{Na}_{2} \mathrm{O}$ & 1.1 & 1.1 & 1.1 & 1.1 & 1.2 & 1.2 & 1.1 & 1.1 & 1.0 & 1.2 & 1.1 & 1.1 & 1.1 & 1.1 & 1.1 & 1.0 \\
\hline $\mathrm{K}_{2} \mathrm{O}$ & 1.0 & 1.0 & 0.9 & 0.9 & 1.0 & 1.1 & 1.0 & 0.9 & 0.9 & 1.0 & 0.9 & 0.9 & 1.0 & 1.0 & 1.0 & 1.0 \\
\hline $\mathrm{P}_{2} \mathrm{O}_{5}$ & 0.0 & 0.0 & 0.0 & 0.0 & 0.0 & 0.0 & 0.0 & 0.0 & 0.0 & 0.0 & 0.0 & 0.0 & 0.0 & 0.0 & 0.0 & 0.0 \\
\hline$\left(\mathrm{SO}_{3}\right)$ & 0.1 & 0.0 & 0.0 & 0.0 & 0.0 & 0.1 & 0.1 & 0.1 & 0.1 & 0.0 & 0.0 & 0.1 & 0.1 & 0.1 & 0.1 & 0.0 \\
\hline LOI & 16.0 & 15.7 & 17.2 & 17.5 & 16.8 & 16.4 & 16.7 & 16.7 & 17.6 & 16.8 & 17.3 & 17.7 & 16.9 & 17.1 & 17.2 & 17.2 \\
\hline Sum & 100.0 & 99.9 & 99.9 & 99.9 & 99.9 & 99.9 & 99.9 & 99.9 & 99.9 & 99.9 & 99.9 & 99.9 & 99.9 & 99.9 & 99.9 & 99.9 \\
\hline \multicolumn{17}{|c|}{ LECO (mass\%) } \\
\hline $\mathrm{C}_{\text {total }}$ & 0.1 & 0.1 & 0.1 & 0.2 & 0.1 & 0.2 & 0.1 & 0.1 & 0.1 & 0.2 & 0.2 & 0.4 & 0.1 & 0.1 & 0.1 & 0.1 \\
\hline $\mathrm{C}_{\text {org }}$ & 0.0 & 0.1 & 0.1 & 0.1 & 0.1 & 0.1 & 0.1 & 0.1 & 0.1 & 0.1 & 0.1 & 0.1 & 0.1 & 0.1 & 0.1 & 0.1 \\
\hline $\mathrm{C}_{\text {carb }}$ & 0.1 & 0.1 & 0.1 & 0.1 & 0.1 & 0.1 & 0.1 & 0.0 & 0.0 & 0.1 & 0.1 & 0.3 & 0.1 & 0.0 & 0.1 & 0.0 \\
\hline $\mathrm{S}_{\text {total }}$ & 0.0 & 0.0 & 0.0 & 0.0 & 0.0 & 0.0 & 0.0 & 0.0 & 0.0 & 0.0 & 0.0 & 0.0 & 0.0 & 0.0 & 0.1 & 0.0 \\
\hline
\end{tabular}


TABle 2. (contd.)

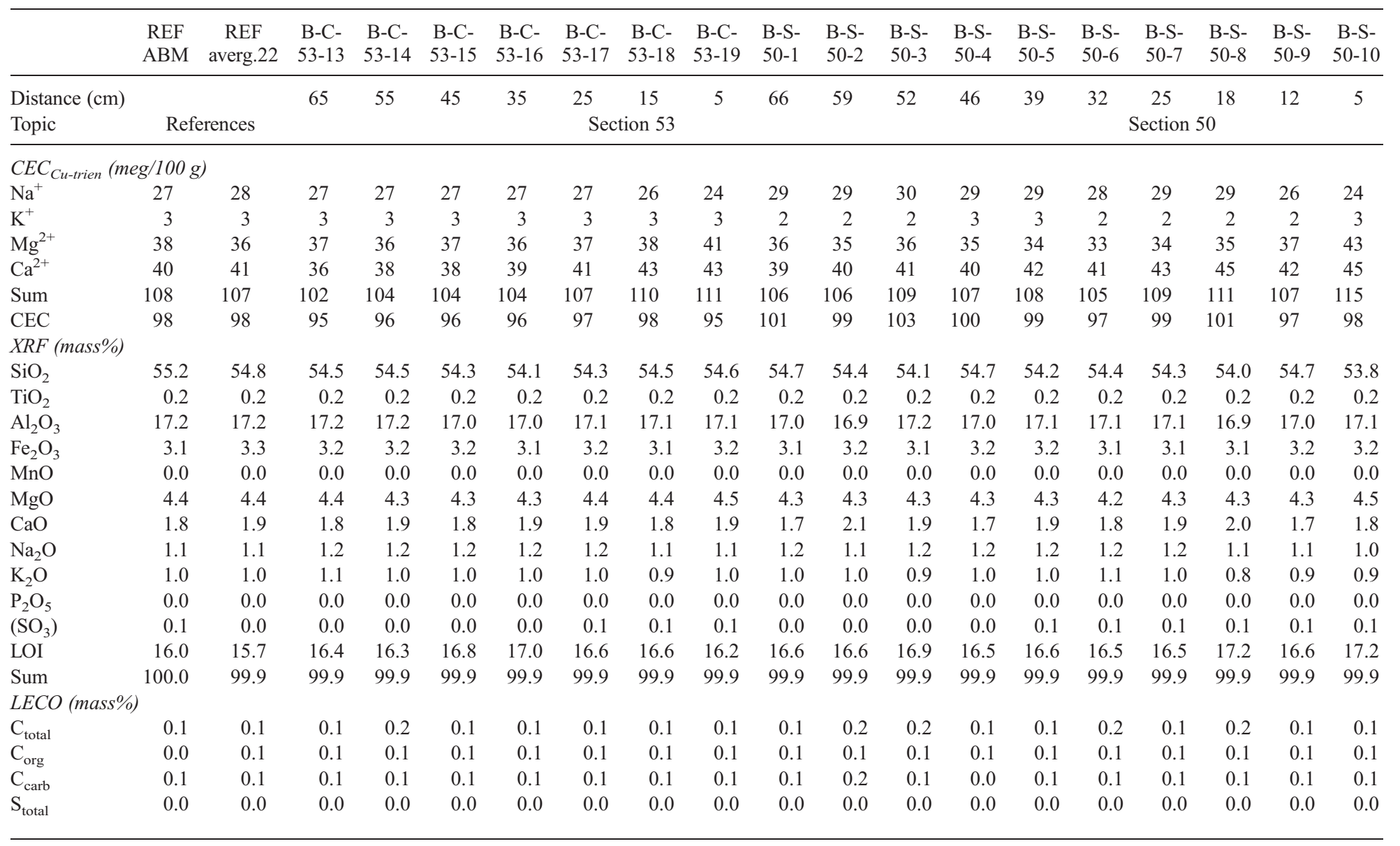


2013; Kaufhold et al., 2013) was used as 'FEBEX reference' (sample before ABM test). The FEBEX $\mathrm{ABM}$ CEC and EC reference data (Table 1) were compared with values determined by Fernández et al. (2001, 2004), who studied the pore water of the FEBEX bentonite and concluded that an equivalent of $\sim 0.13$ mass $\% \mathrm{NaCl}$ was present in the bentonite in excess of actually exchangeable $\mathrm{Na}^{+}$. This mass equals $2.3 \mathrm{meq} /$ $100 \mathrm{~g}$ exchangeable $\mathrm{Na}^{+}$, which was subtracted from the reference values to reflect only exchangeable $\mathrm{Na}^{+}$. Exchangeable $\mathrm{Na}^{+}$values of the FEBEX ${ }_{\mathrm{ABM}}$ reference (27 meq/100 g) were identical to those of Dohrmann et al. (2013), but slightly lower than those of Fernández et al. (2004) (29 meq/100 g). Dohrmann et al. (2013) studied the $\mathrm{FEBEX}_{\mathrm{ABM}}$ reference clay using the socalled 'Cu-trien ${ }_{5 \times \text { calcite }}$ ' method in which the exchange solution was pre-saturated with respect to calcite in order to avoid further calcite dissolution during the $\mathrm{CEC}$ experiment. These authors reported $7 \mathrm{meq} / 100 \mathrm{~g}$ less exchangeable $\mathrm{Ca}^{2+}$ caused by the presence of partly soluble $\mathrm{Ca}$ phases. In addition to the $\mathrm{FEBEX}_{\mathrm{ABM}}$ reference, 22 of those samples investigated in the present study were selected and the values averaged to calculate a 'FEBEX 22 reference'. These 22 samples were taken at a distance of $>10 \mathrm{~cm}$ from the heater and from the granite, and the average values of the $\mathrm{FEBEX}_{22}$ reference samples showed no variation with respect to the chemical composition and exchange quantities.

The carbonate content of the 'FEBEX 22 reference material' based on XRD Rietveld analysis (calcite 1 mass\%) was in good agreement with the LECO data (0.1 mass\% $\mathrm{C}$, which corresponds to $0.8-0.9$ mass $\%$ calcite), whereas the difference of $7 \mathrm{meq} / 100 \mathrm{~g}$ exchangeable $\mathrm{Ca}^{2+}$ indicates calcite content of $\sim 0.3$ mass\%. Fernández \& Villar (2010) reported $0.60 \pm$ 0.13 mass $\%$ calcite plus dolomite (taken from Fernández et al., 2004). It is not clear whether these differences might be explained by uptake of $\mathrm{HCO}_{3}^{-}$ during water uptake followed by precipitation of calcite in the $\mathrm{FEBEX}_{22}$ reference material. The evolved gas analysis of thermally induced gases indicated the presence of at least traces of a sulfate mineral, but sulfides were not identified $(<0.01$ mass $\%)$. The $\mathrm{K}_{2} \mathrm{O}$ content may be explained by 5 mass $\%$ K-feldspar resulting in $\sim 0.85$ mass $\% \mathrm{~K}_{2} \mathrm{O}$ and some exchangeable $\mathrm{K}^{+}$in the smectite or illite layers $\left(\sim 0.14\right.$ mass $\left.\% \mathrm{~K}_{2} \mathrm{O}\right)$.

FEBEX bentonite as used in the ABM test in Äspö contains smectite with varying hydration states when analysed in air-dried conditions. This might be described as interstratification of smectites with varying numbers of water layers. The coexistence of varying hydration states is a common phenomenon of smectites (Ferrage et al., 2005). Exchangeable $\mathrm{Mg}^{2+}$ values of the FEBEX ${ }_{\mathrm{ABM}}$ reference $(38 \mathrm{meq} / 100 \mathrm{~g})$ were approximately identical to those reported by Dohrmann et al. (2013) (37 meq/100 g), but larger than those of Fernández et al. (2004), who used Ni(en) (34 meq/100 g) and $\mathrm{Cs}^{+}(32 \mathrm{meq} / 100 \mathrm{~g})$ index cations for extraction. Overall, the chemical data confirm the mineralogical composition determined by Rietveld analysis. The results are in good agreement with those published by Lanyon \& Gaus (2013), for example, except for the varying feldspar contents. The Rietveld refinement yielded 14 mass $\%$ feldspar, while $\sim 3$ mass $\%$ had been reported in previous studies. For quantification of the mineralogical composition, Rietveld analysis was performed using the same parameters for all samples. This is the prerequisite for a possible identification of differences of samples based on quantitative XRD.

\section{Cement (shotcrete)/bentonite}

Samples taken at the contact with the cement (shotcrete) interface (two samples each representing $\sim 20 \mathrm{~cm}^{2}$ interface) showed an increase of $\mathrm{MgO}, \mathrm{C}$ and $\mathrm{S}$ (Table 1, BC-S-35 samples). In addition, a marked decrease of the CEC was found for the $0.1 \mathrm{~cm}$ samples. These were investigated using XRD, IR spectroscopy and STA and were compared with the reference (Fig. 3). In the contact samples, a new band at $\sim 3698 \mathrm{~cm}^{-1}$ was observed (Fig. 3a). This band may be attributed either to brucite $\left(\mathrm{Mg}(\mathrm{OH})_{2}\right)$ or to kaolinite or even to a different $\mathrm{Mg}$-silicate-hydrate phase containing $\mathrm{Mg}(\mathrm{OH})_{2}$. At $\sim 570 \mathrm{~cm}^{-1}$, a small shoulder was observed (spectral range not shown), which would point to brucite and hence would also explain the observed $\mathrm{MgO}$ increase. In the STA (MS curve $\mathrm{m}=18$; Fig. 3b), a new dehydroxylation peak at $\sim 530^{\circ} \mathrm{C}$ was observed. This peak might also result from formation of either kaolinite or brucite (or Mg-silicate-hydrate phases).

The XRD texture slide (Fig. 3c) confirmed the full expandability of the smectite and showed traces of illite-muscovite ( $\sim 0.1$ mass $\%$ according to the $\mathrm{K}_{2} \mathrm{O}$ increase) and some intensity at $\sim 7 \AA$, which might be attributed to kaolinite. In addition, a broad peak was also observed pointing towards brucite, but based on this peak even Rietveld did not provide unambigous evidence for the existence of brucite. In summary, either kaolinite or brucite (or a similar phase) formed at the cement/shotcrete contact, along with carbonates and sulfates. According to Turrero \& Cloet (2017), "the porewater conditions at the interface are favourable for the formation of Mg-rich precipitates." All analyses (IR spectroscopy, LECO, STA) confirmed a 

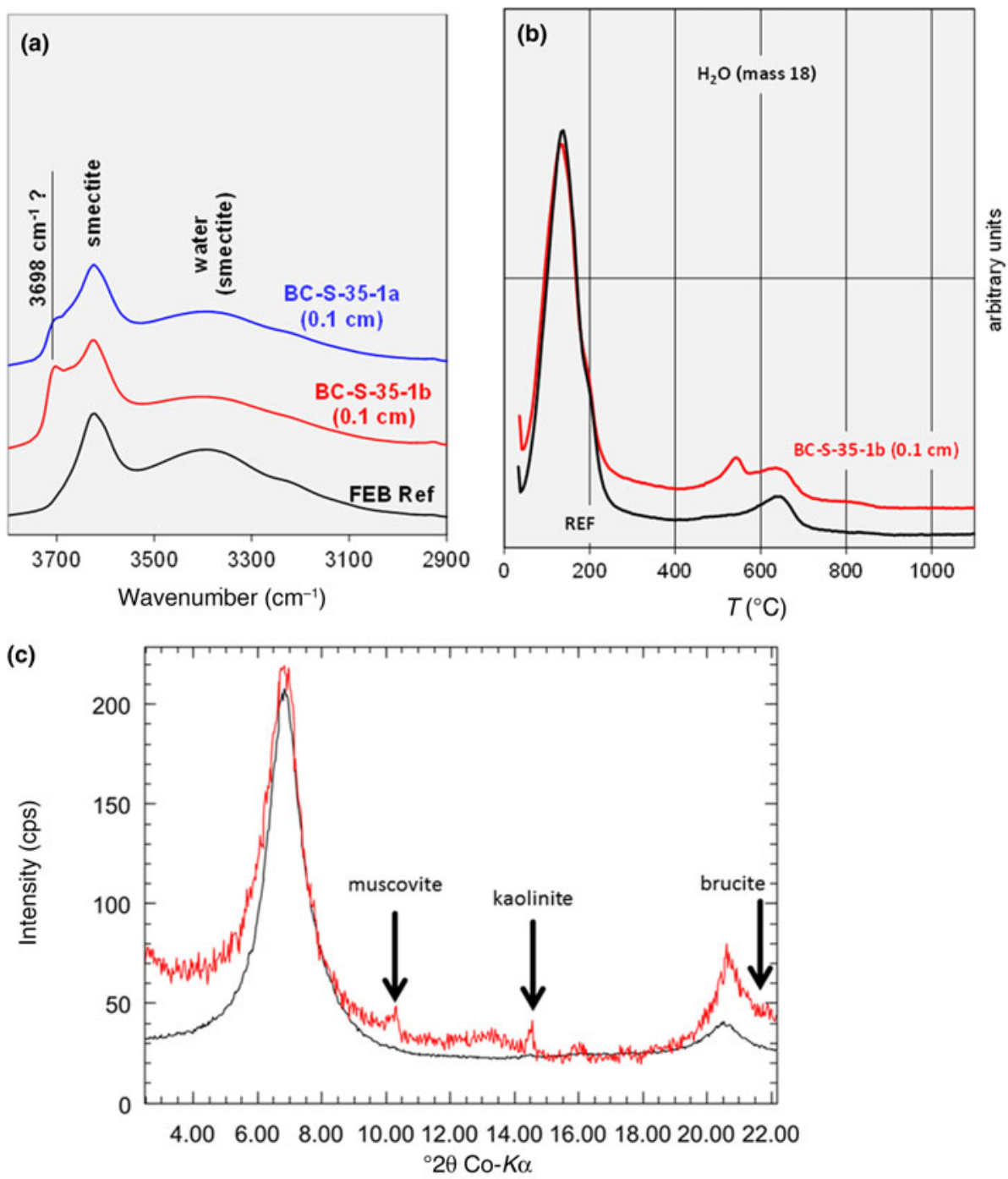

FIG. 3. Mineralogical characterization of the cement/shotcrete contact sample. (a) IR spectra; (b) STA-MS curve; (c) $\mathrm{XRD}$ texture slide (air dried). Black = reference; red = BC-S-35-1b.

slight increase in carbonate and sulfate contents, which might have resulted from the cement/shotcrete, which consists of silicates, carbonates and gypsum. At the contact ( $1 \mathrm{~mm}$ sample), a significant decrease in the CEC was observed $(25-50 \%)$. Even at a distance of $1 \mathrm{~cm}$, a CEC decrease of $5-10 \%$ was recorded $(1 \mathrm{~cm}$ samples in Table 1). This might be explained by the $\mathrm{pH}$ effect on the CEC (caused by the cement/shotcrete) because the CEC increases with increasing $\mathrm{pH}$. The CEC decrease, therefore, points either towards smectite alteration or towards a dilution effect caused by the precipitation of cement phases in the bentonite pores.
The contact between bentonite and cement/shotcrete was also investigated by SEM (Fig. 4). A slightly brighter transition zone appeared in the backscatter electron images (Fig. 4a), which varied from a few hundred micrometres up to $1 \mathrm{~mm}$ in width. Within this transition zone, crystallization of fine particles was observed. Because of their small particle size, no reliable EDX data were obtained. In contrast, Turrero et al. (2017) observed a reaction zone of $\sim 1 \mathrm{~cm}$ in which most of the mineral alterations were observed. In the sample investigated in the present study, microcracks were observed, in agreement with Turrero \& 

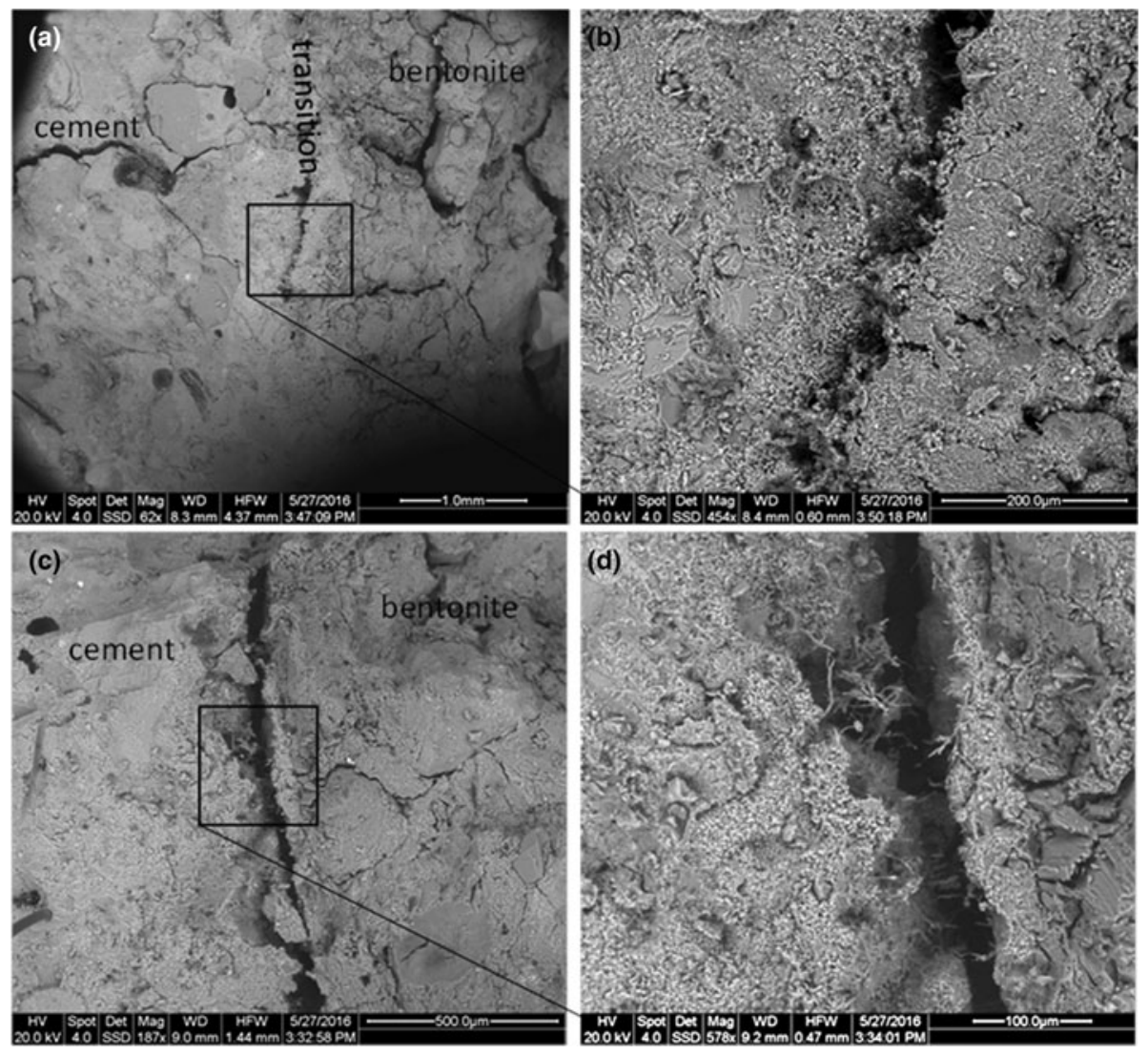

FIG. 4. SEM investigation of the cement/shotcrete bentonite interface. (a) and (c) represent different SEM investigation spots and (b) and (d) are close-ups showing the area marked by the squares in (a) and (c), respectively.

Cloet (2017). The CEC indicated mineralogical alteration up to a distance of $1 \mathrm{~cm}$ from the contact. The reaction zone identified by SEM, however, was $<1 \mathrm{~cm}$. The reason for the CEC decrease at the $1 \mathrm{~cm}$ distance might be due to solid-state reactions (such as collapse of interlayers or cation exchange) that did not affect the clay microstructure and hence were not detected by SEM. Turrero \& Cloet (2017) reported possible preferential fluid pathways that would explain changes in the pore-water composition, hence leading to cation exchange.

\section{Iron/bentonite}

The iron heater was surrounded by a perforated liner also made of iron (see e.g. Huertas et al., 2006). Some air was trapped between both iron elements. In the current disposal concepts, no such air-filled volumes exist. The contact samples taken from blocks 36 (liner/ dummy) and 42 (liner/heater) showed reddish colours that corresponded to increased $\mathrm{Fe}_{2} \mathrm{O}_{3}$ contents. The XRD Rietveld refinement, STA and IR spectroscopy proved the presence of goethite (patterns and spectra not shown). The presence of goethite points towards oxic corrosion. The goethite $/ \mathrm{Fe}_{2} \mathrm{O}_{3}$ increase was 2-3 mass $\%$ in the first millimetre of the bentonite. More information about corrosion was gained from the investigation of the 'E samples' (Table 1) that were collected at specific interfaces (see Fig. 2).

The $\mathrm{MgO}$ increases in the $\mathrm{E}$ samples were small despite the fact that the E samples were taken directly from or at least near the liner. Only a slight increase in $\mathrm{MgO}$ was observed in the grey material collected between the heater and liner. Samples E2, E3 and E5 showed elevated $\mathrm{Fe}$ contents. By far the largest $\mathrm{Fe}$ increase was recorded in sample E6. For samples E7 and E8 (white crust inside liner), marked increases of both $\mathrm{C}$ and $\mathrm{CaO}$ were detected, which might be explained by the presence of aragonite and reduced amounts of dolomite (Table 1). In sample E2 (reddish, 
scratched off the inside of the liner), goethite was detected by XRD. Except for a slightly lower carbonate content, samples E3 and E4 were similar to the reference. These samples probably swelled through the holes of the liner into the space between the liner and heater. Some of the carbonate was dissolved and apparently accumulated at the inner liner surface (samples E7 and E8). No newly formed Fe phases were observed in sample E3, although the $\mathrm{Fe}_{2} \mathrm{O}_{3}$ content increased by $\sim 3$ mass $\%$.

In contrast, the black crust (sample E6) scratched off the liner contained siderite and magnetite, but also the primary components of bentonite (as smectite). Traces of native $\mathrm{Fe}$ were also detected in this sample, pointing towards an intimate intergrowth of both the metal surface and bentonite. For Rietveld refinement, it was advantageous to add a maghemite structure (which yielded a better fit). The actual presence of maghemite, however, is difficult to verify. Interestingly, sample E6 showed a $10 \AA$ intensity that was described as muscovite in the XRD Rietveld analysis. Muscovite, however, was present in neither the bentonite nor the metal. Some smectite may have collapsed upon dehydration to $10 \AA$ and hence was described as muscovite in the Rietveld refinement. It may also be that real muscovite formed, but the $\mathrm{K}$ content decreased, which would not correspond to the formation of muscovite. In the white crust, $>30$ mass $\%$ carbonates were detected by XRD, which was confirmed by both IR spectroscopy and STA (data not shown).

Interestingly no $\mathrm{Fe}_{2} \mathrm{O}_{3}$ increase was observed in the contact samples taken from block 54 . This block was in direct contact with the heater and not with the liner, which means that little air was entrapped there that could have led to oxic corrosion. Anaerobic corrosion, on the other hand, which might be the dominant process affecting the heater in the long run, was not observed.

\section{Mg increase}

At the heater-bentonite interface, both an increase in the metal content $(\mathrm{Cu}$ or $\mathrm{Fe})$ as well as an increase in the $\mathrm{Mg}$ content were observed in previous tests (Karnland et al., 2009; Kaufhold et al., 2013; Svensson, 2015). These effects, however, were restricted to the contact and hence were only detectable in the contact samples. Yet metal corrosion and $\mathrm{Mg}$ increase have been observed at the same time, but to varying extents. In the contact sample of block 36 , for example, an $\mathrm{Fe}_{2} \mathrm{O}_{3}$ increase of 4 mass $\%$ but no $\mathrm{Mg}$ increase was detected. The special history of this block was described by Wersin \& Kober (2016). A smaller Fe increase but a slightly larger $\mathrm{MgO}$ content was observed in one of the contact samples of block 42 . The $\mathrm{MgO}$ increase, however, was insignificant $(+0.5$ mass $\%$ ) and hence is not discussed further. A significant increase in the $\mathrm{MgO}$ content, however, was observed in the contact sample of block 54. This block was in direct contact with the heater surface and not with the liner as in the other samples. No signs of corrosion were detected, but the $\mathrm{MgO}$ content increased by 5.7 mass\% (from 4.4 to 10.1 mass\%), which is larger than the $\mathrm{MgO}$ increase reported from the ABM tests (Karnland et al., 2009; Kaufhold et al., 2013, 2017; Svensson, 2015). This contact, therefore, was investigated in more detail to identify the $\mathrm{Mg}$ phase and to draw conclusions about the reaction mechanism. Two samples (BM-S-54-5B-1 and BM-S54-5C-3; Table 1) were taken from the contact surface of block 54. In previous tests, the $\mathrm{MgO}$ increase was accompanied by the formation of trioctahedral domains that were detected by powder XRD (Fig. 5) and IR spectroscopy. The initially collected amount of sample from the block was not sufficient for XRD Rietveld analysis. A new sample, therefore, was taken and denoted as BM-S-54-1NH.

For sample BM-S-54-5B-1 with the largest $\mathrm{MgO}$ increase, a new peak was found at $1.54 \AA$, which indicated the presence of trioctahedral domains or phases. In addition, a marked decrease of the CEC was observed (almost 40\% for sample BM-S-54-5B-1). The amount of exchangeable $\mathrm{Na}^{+}$decreased, while exchangeable $\mathrm{Mg}^{2+}$ increased. The XRD Rietveld refinement of the pattern shown in Fig. 5 revealed the presence of a trace of brucite in the contact samples. No clear reflection of brucite was observed, however. The presence of kaolinite was ruled out based on the oriented XRD mount (Fig. 6b).

The formation of brucite would explain the $\mathrm{MgO}$ increase, but not the presence of the $1.54 \AA$ reflection (Fig. 5). Therefore, XRD indicated the formation of both brucite and trioctahedral sheet silicates. Interestingly, XRD Rietveld refinement did not reveal a decrease in the smectite content, although the CEC was markedly reduced. The expandability was proven by XRD, using texture slides (upon EG treatment, the peaks shifted to $17 \AA$; Fig. 7). A slightly lower value was found for sample BM-S-54-1NH (16.7 $\AA$ ). This difference, however, does not allow the conclusion of reduced swelling capacity. Differences in the peak positions of the patterns were mainly caused by a small sample displacement error during XRD analysis. Both the reference and the contact sample show full expandability with EG. The intensity differs, 


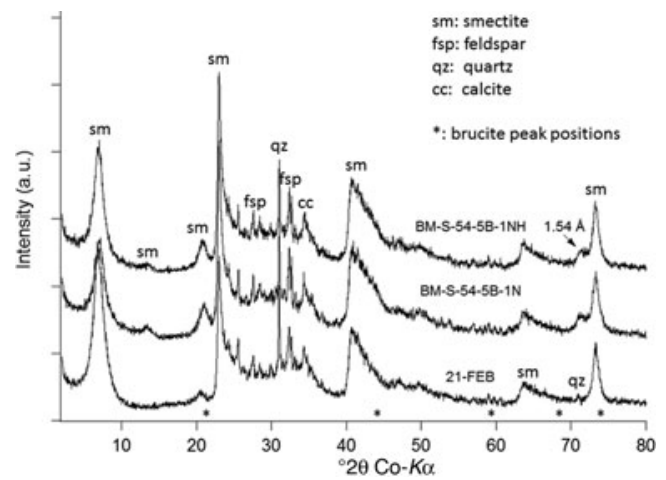

FIG. 5. XRD powder diffraction data of the reference (sample 21-FEB) and samples taken from the contact of block 54. The originally taken sample (BM-S-54-5B-1) was insufficient for XRD. Therefore, two new samples were scratched off the surface and denoted as BM-S-54-

$5 \mathrm{~B}-1 \mathrm{~N}$ and BM-S-54-5B-1NH ('N' = new).

however, which points towards varying degrees of preferred orientation.

Kaolinite formation was ruled out based on XRD, which assisted in interpretation of the IR spectra (Fig. 6a). In the IR spectrum, a new band was observed at $\sim 3698 \mathrm{~cm}^{-1}$, which was assigned to brucite because of the absence of kaolinite. In addition, a slight increase in intensity of the contact sample was observed at 570 and $440 \mathrm{~cm}^{-1}$, which might be explained by brucite (Fig. 6a). The band at $680 \mathrm{~cm}^{-1}$ was used to identify the formation of trioctahedral domains/sheet silicates in previous studies (Kaufhold et al., 2013). For the contact sample of block 54, a slight increase in intensity but no distinct band was observed. The $680 \mathrm{~cm}^{-1}$ band cannot be interpreted unambiguously. In addition, a slight increase in the IR intensity at $\sim 880 \mathrm{~cm}^{-1}$ was observed, which would be explained by formation of $\mathrm{AlFeOH}$ bonds, but not by either kaolinite or brucite (compare with grey reference spectra in Fig. 6a). In addition, the Fe increase was small, accounting for the formation of $\mathrm{AlFeOH}$ bonds.

The contact at the front of the heater was also investigated using SEM (Fig. 8). It is represented by an even surface with small white spots. As expected, the $\mathrm{Mg}$ content was slightly greater at the surface, but actual values differed depending on the EDX spot position. In addition, the bright spots on the surface were rather small $(<100 \mathrm{~nm})$. No EDX data could therefore be collected to represent the white spots. These white spots might represent neoformed minerals because they were not detected anywhere else in the sample except for at this interface. These particles might be brucite or a Mg-rich clay mineral. Interestingly, the zone in which the white spots formed is rather thin $(\sim 5 \mu \mathrm{m})$. Therefore, methods with higher resolutions should be applied in order to further characterize the white spots. This block will be investigated in more detail in a follow-up project. Notably, such precipitations might also form upon cooling after termination of the heating period.

\section{Water content}

After drilling, the samples were dried at $60^{\circ} \mathrm{C}$ and the water loss was determined (Fig. 9). An aliquot of this material was used to determine the further mass loss at $60-105^{\circ} \mathrm{C}$ ( 1 week of drying). The results are in good agreement with those published by Villar et al. (2016). The water content near the heater ranged from 20 to 24 mass $\%$ and increased towards the granite up to 26-28 mass\%. Similar water contents were recorded at various sampling sites. The water content gradient has to be taken into account when interpreting the geochemical results and particularly when comparing them with other large-scale tests.

\section{CEC/cation migration}

The most suitable samples for studying cation exchange processes and cation migration through the entire barrier were those taken from the profiles (Fig. 1) of sections 45, 50 and 53. All of the different sections showed comparable trends: exchangeable $\mathrm{Mg}^{2+}$ showed a sharp increase towards the heater that corresponded to a decrease in exchangeable $\mathrm{Na}^{+}$in this part (Table 1, Fig. 10). This was confirmed by Villar (2017; NAB 16-017) who studied sections 47 and 53 of the FEBEX experiment after dismantling. The concentration of exchangeable $\mathrm{Mg}^{2+}$ was lower compared to the FEBEX $\mathrm{ABM}_{\mathrm{BM}}$ reference material in most parts of the profile (65 to $\sim 10 \mathrm{~cm}$ ), except for samples collected near the heater. The concentration of exchangeable $\mathrm{Na}^{+}$, on the other hand, was slightly larger in distances from the heater surface ranging from 65 to $\sim 10-30 \mathrm{~cm}$. Near the heater, the opposite trend was observed. The similar shape of the curves for exchangeable $\mathrm{Mg}^{2+}$ and $\mathrm{Na}^{+}$indicated a cation exchange process and hence a larger $\mathrm{Mg}^{2+}$ concentration in the pore water near the heater.

Careful evaluation of the anion concentration of pore water is necessary in order to evaluate the proportion of actually exchangeable $\mathrm{Na}^{+}$that was influenced by unknown amounts of excess $\mathrm{NaCl}$ dissolved in the pore water ( $c f$. Fernández et al., 

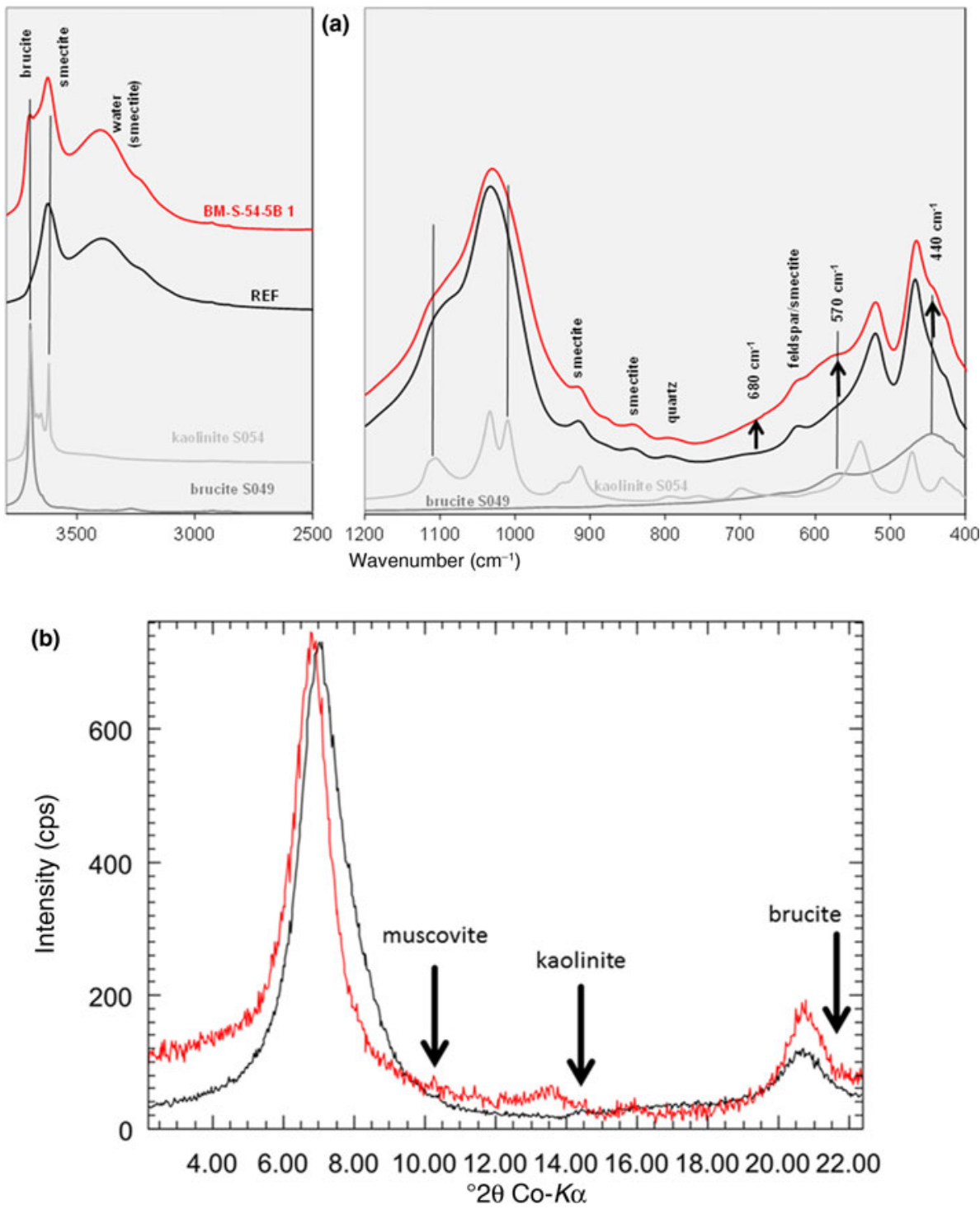

FIG. 6. IR spectrum (a) and XRD texture slide pattern (b) (air dried) of the reference material (black) and the contact sample BM-S-54-5B-1 (red).

2001). Strongly increasing $\mathrm{Cl}^{-}$contents with respect to the reference material close to the heater have been observed in aqueous extracts of sections 47 and 53 that correlated with increasing $\mathrm{Na}^{+}$content (Villar, 2017). On the other hand, both $\mathrm{Cl}^{-}$and $\mathrm{Na}^{+}$decreased in the colder regions. $\mathrm{Ca}^{2+}$ and $\mathrm{SO}_{4}^{2-}$ correlated similarly, but showed maxima at $10-30 \mathrm{~cm}$ distances from the bentonite-heater interface. Exchangeable $\mathrm{Ca}^{2+}$, on the other hand, showed trends similar to the water-content curves (Fig. 10). Both parameters may be systematically related because the proportion of pore water determines the solubility of carbonates and sulfates.

The exchangeable $\mathrm{Ca}^{2+}$ was compared with the inorganic carbon content (Fig. 11a) and total sulfur (Fig. 11b). The error in exchangeable $\mathrm{Ca}^{2+}$ induced by calcite dissolution during the CEC experiment should be proportional to the carbonate content. Interestingly, the inorganic carbon content showed the opposite 


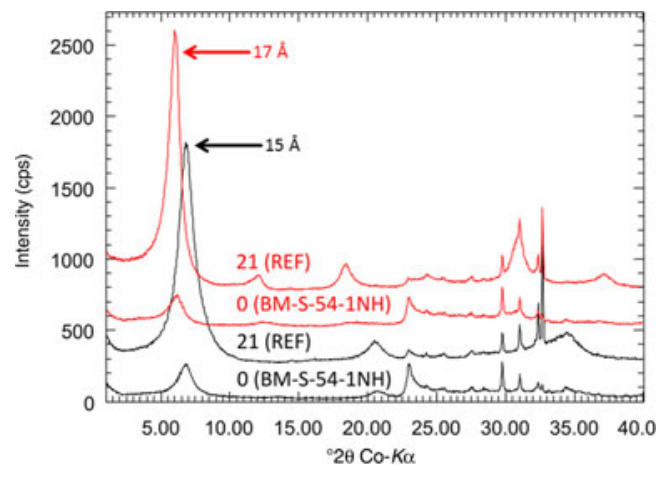

FIG. 7. XRD texture slide analysis (black: air dried; red: EG) of the contact sample.

trend. Despite appreciable scatter, larger carbonate contents were observed at a considerable distance from the heater. The carbonate content, therefore, does not determine the amount of exchangeable $\mathrm{Ca}^{2+}$. The $\mathrm{S}$ content, on the other hand, was close to the detection limit. Nevertheless, larger values were detected closer to the heater. The $\mathrm{Ca}^{2+}$ curve, therefore, could possibly be explained by the redistribution of sulfates. The $\mathrm{S}$ values, however, are small -0.05 mass $\% \mathrm{~S}$ corresponding to 0.25 mass $\%$ gypsum. Based on a sample mass in the CEC experiment of $100 \mathrm{mg}, 0.07 \mathrm{mg} \mathrm{Ca}$ would be available from gypsum, which corresponds to only $0.2 \mathrm{mmol} / 100 \mathrm{~g}$. The gypsum content, therefore, does not explain the Ca curve.

The opposite trends of carbonate and exchangeable $\mathrm{Ca}^{2+}$ cannot be explained with the existing data. It is possible that some $\mathrm{CaCl}_{2}$ was present in the pore water, but in that case, the opposite trend would be expected, because more pore water was present in samples further away from the heater. Villar (2017), on the other hand, subtracted excess $\mathrm{Ca}^{2+}$ from soluble Ca phases by means of anion analysis of samples taken from section 50. Taking into account these corrections, the exchangeable $\mathrm{Ca}^{2+}$ values remained around the value for the reference bentonite. In the long-term test of buffer material project (LOT), no such gradients of ECs were detected (Karnland et al., 2009), but various gradients were observed in the first package of the ABM project (ABM-I; Dohrmann et al., 2013; Wallis et al., 2015) and in the second package (ABM-II; Dohrmann \& Kaufhold, 2017).

However, it is not clear why varying profiles were observed. The degree of water saturation might be important. The FEBEX groundwater has $\mathrm{pH} 9.6$ and low salinity (Na-Ca-HC03-F type; Degueldre, 1994) with $0.7 \mathrm{mM} \mathrm{Na}$ and $0.14 \mathrm{mM} \mathrm{Ca}$. Other cations are present in traces: $2.1 \mu \mathrm{M} \mathrm{Mg}, 2.3 \mu \mathrm{M} \mathrm{Sr}$ and $3.6 \mu \mathrm{M}$ $\mathrm{K}$. Although the groundwater is almost free of $\mathrm{Mg}^{2+}$, this did not decrease the exchangeable $\mathrm{Mg}^{2+}$ values of the bentonites. The low $\mathrm{Mg}$ content, on the other hand, suggests that the $\mathrm{Mg}$ that accumulated at the bentoniteheater interface stemmed from some incongruent dissolution of smectites. Fernández \& Villar (2010) also reported on increasing exchangeable $\mathrm{Mg}^{2+}$ values of FEBEX bentonite samples in column tests after 7.6 years of heating and hydration (up to $+10 \mathrm{meq} / 100 \mathrm{~g}$ close to the heater). Those authors used a Ca-Na-Mgtype water for saturation with a 200 -fold larger Mg content compared to the FEBEX groundwater (Ca was 8 -fold more concentrated and the Na content was 0.66 fold greater compared to the FEBEX groundwater). Although the $\mathrm{Mg}$ concentration was large in the water
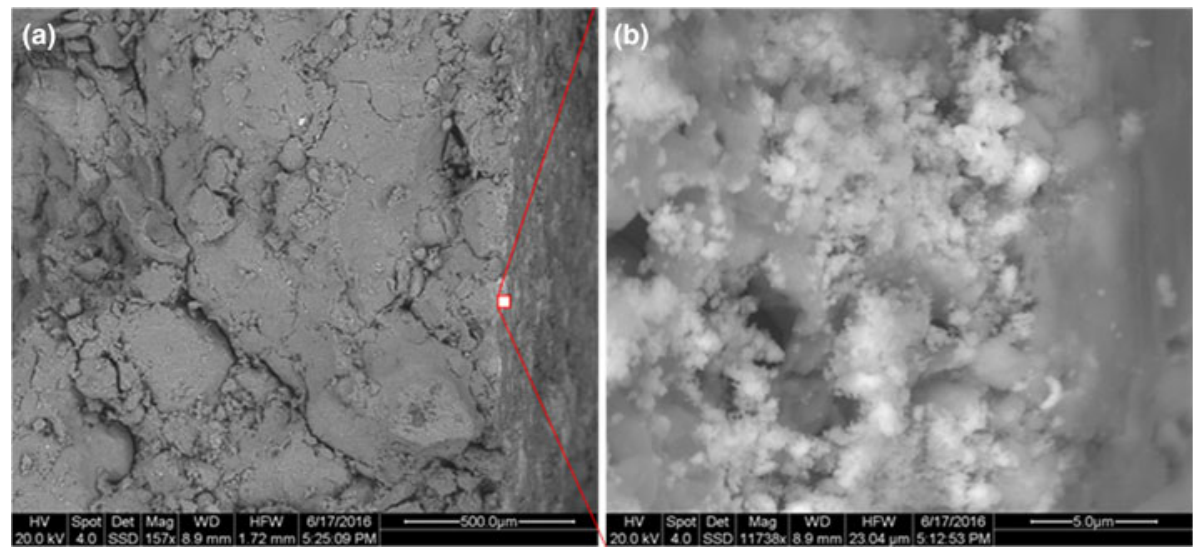

FIG. 8. SEM investigation of the contact at the front of the heater. The white spots in (a) can be best observed in the closeup image in (b). 

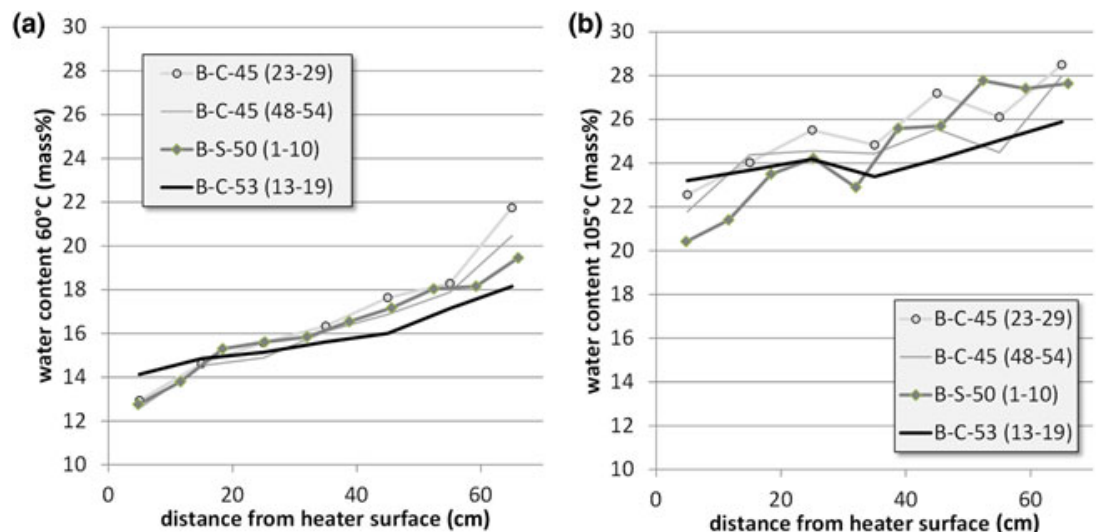

FIG. 9. Water contents of the bentonite profiles of three sections determined at $60^{\circ} \mathrm{C}$ (a) and $105^{\circ} \mathrm{C}$ (b).

used by Fernández \& Villar (2010), the resulting exchangeable $\mathrm{Mg}^{2+}$ values were not larger than those found in samples after reaction with the FEBEX groundwater used in this experiment.

The CEC is probably the most important parameter for evaluating the performance of a barrier in crystalline rocks because it reflects the swelling capacity of the bentonite and may be determined with comparably high precision. The CEC values remained unaffected in all profiles, which indicated that smectites remained expandable. These CEC values, however, corresponded to samples taken at least a few centimetres from the heater surface. Samples taken directly from the contact
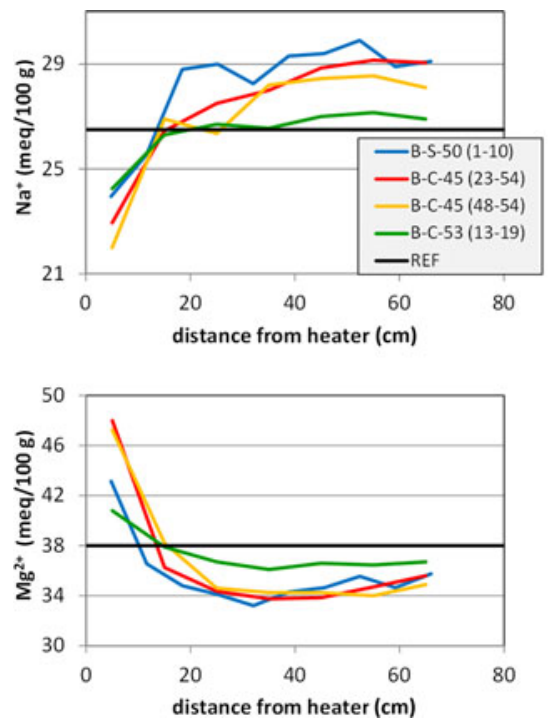

show some decrease in the CEC (results presented above), which proved the loss of some swelling capacity of the smectite that, however, is restricted to the very contact.

Apart from cations, anions might also migrate through the barrier, with ${ }^{129} \mathrm{I}^{-}$being particularly hazardous (Kaufhold et al., 2007). In the frame of the FEBEX experiment, iodide migration tests were installed (yellow bar in Fig. 1). In section 50, iodidesaturated filter papers were placed between the granite and bentonite. Such a tracer was similarly installed in section 30 and investigated during the partial dismantling in 2002 (ENRESA, 2006). The iodide
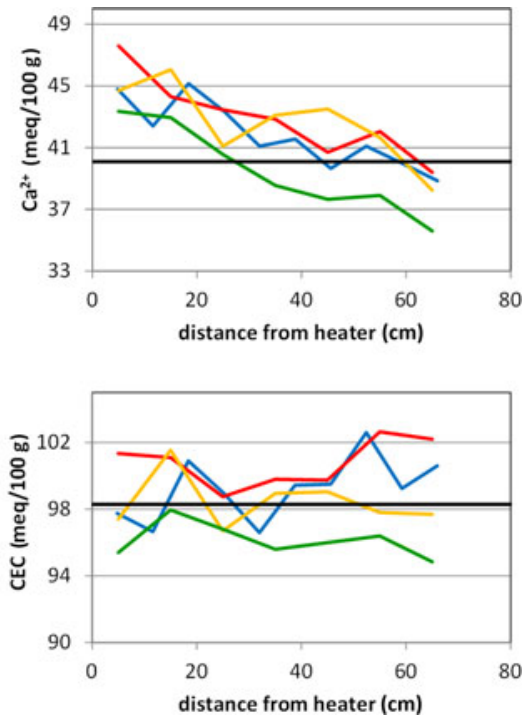

FIG. 10. ECs of the profiles (data from Table 2). 

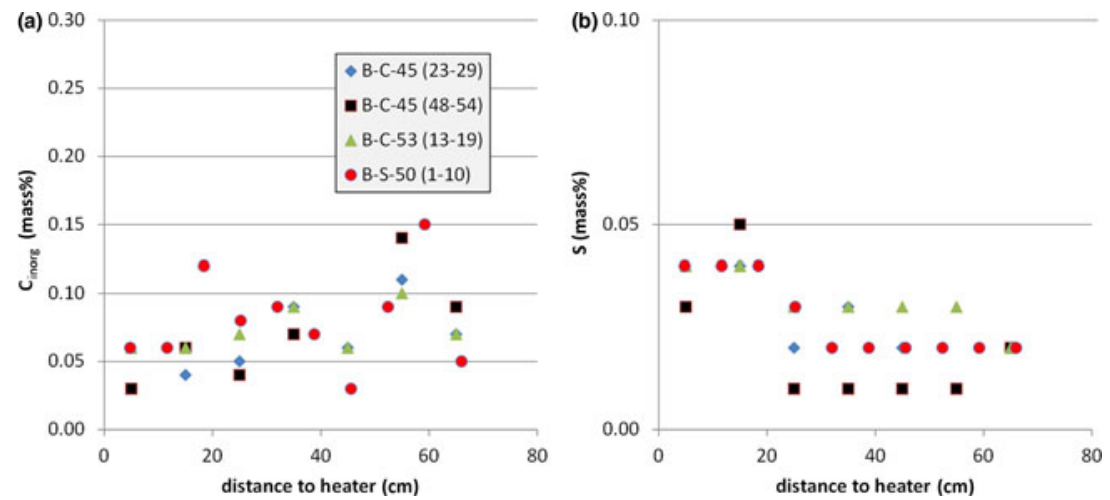

FIG. 11. Inorganic C content (a) and S content (b) depending on the distance from the heater (four profiles).

concentration depended on the distance to the gallery axis (to the heater) and varied from 0.2 to $\sim 2.0 \mathrm{mg} / \mathrm{g}$ $(=0.02-0.20 \%=200-2000 \mathrm{mg} / \mathrm{kg}=200-2000 \mathrm{ppm})$. Interestingly, a higher iodide concentration was recorded near the heater, although the iodide tracer was further away. This behaviour corresponds to the expected behaviour of a tracer following water migration (ENRESA, 2006). For the present study, XRF powder analysis was used to detect the iodide. The detection limit was $0.5 \mathrm{mg} / \mathrm{kg}$. Both references and all but one of the samples of the iodide profile showed iodide concentrations of $<0.5 \mathrm{mg} / \mathrm{kg}$. Only for the sample that was far away from the iodide paper was a value above the detection limit measured. This might be explained based on the results reported for section 30 (ENRESA, 2006), but this value $(0.6 \mathrm{mg} / \mathrm{kg})$ is close to the detection limit and hence should be treated with caution. The iodide concentration in this profile is $\sim 4000$-fold less than that of section 30 (ENRESA, 2006). The XRF trace element analysis indicated that either iodide did not diffuse through the bentonite barrier at all or was washed out. In section 30, significant iodide concentrations were found (after less time). Therefore, it is more probable that the iodide diffused away.

\section{SUMMARY AND CONCLUSIONS}

The current study presents geochemical and mineralogical investigations of interfaces and selected profiles of the FEBEX experiment. At the cement/shotcretebentonite interface, a reaction zone of $0.1-1.0 \mathrm{~mm}$ was observed. This is characterized by the precipitation of carbonates and sulfates. In addition, a trace of either kaolinite or brucite (or a related phase) formed that could not be identified unambiguously. Cation exchange data proved that the chemical impact of the cement on the bentonite was not restricted to $1 \mathrm{~mm}$ because cation exchange and a slightly lower CEC was observed at a distance of even $1 \mathrm{~cm}$ from the cement.

Bentonite samples in contact with the metal liner showed an increase in the Fe content, which was mainly present as goethite. This oxic corrosion may be explained by the comparably large amount of air that was entrapped between the heater and the liner. Samples taken directly from the Fe surface of the liner showed an intimate intergrowth of bentonite constituents and $\mathrm{Fe}$ phases - even native Fe. In addition, precipitation of carbonates at the inner surface of the liner was observed. At the face of the heater (section 54), where bentonite blocks were in direct contact with the heater surface, no signs of corrosion were detected. Instead, a marked increase in the $\mathrm{Mg}$ content was observed.

An increase in the Mg content at the contact with the heater was detected in many previously published descriptions of large-scale disposal tests. For samples taken in section 54, however, the largest $\mathrm{Mg}$ increase accounting for +5.7 mass $\% \mathrm{MgO}$ was recorded. X-ray diffraction revealed the formation of trioctahedral domains or phyllosilicate minerals, as previously reported, but also the formation of brucite, which was also detected by IR spectroscopy. Using SEM, white spots were observed on the contact surface, and the overall thickness of the reaction zone was $\sim 5 \mu \mathrm{m}$. The EDX analysis indicated a large $\mathrm{Mg}$ content of these phases, but because of their small size of $<100 \mathrm{~nm}$, no representative chemical analyses were obtained by SEM. These results help with the understanding of the mechanism behind the Mg enrichment that is needed for reasonable modelling. The large $\mathrm{Mg}$ enrichment in section 54 where no corrosion was observed proved that the $\mathrm{Mg}$ enrichment is not related to Fe corrosion. In 
addition, the presence of two Mg-rich phases proves that formation of trioctahedral domains results from $\mathrm{Mg}$ enrichment. In conclusion, $\mathrm{Mg}$ - which is particularly soluble and may be from cation exchange and incongruent dissolution of silicates - was possibly precipitated in the hot contact zone where the water content was lower. Precipitation of $\mathrm{Mg}$ phases at the contact, in turn, resulted in a $\mathrm{Mg}$ concentration gradient, leading to further $\mathrm{Mg}$ migration towards the heater. This model has to be validated based on laboratory tests and chemical modelling.

Dissolution and precipitation processes were observed in previous large-scale disposal tests. In the FEBEX experiment, a slight decrease in the carbonate content at the heater was observed, particularly when goethite formed. At the same time, aragonite was observed at the inner liner surface. A slight variation in the carbonate content of the blocks was detected, which might be explained by material heterogeneity.

The investigation of the water content of the profile samples proved that water saturation in bentonite has not been achieved. Larger water contents were found near the granite towards the heater.

The FEBEX groundwater is a Na-Ca-HC03-F type and is of low salinity. Water taken up during saturation might explain the increasing exchangeable $\mathrm{Na}^{+}$and $\mathrm{Ca}^{2+}$ values. However, this was only partly confirmed after dismantling. Exchangeable $\mathrm{Mg}^{2+}$ shows a sharp increase towards the heater, corresponding to a decrease of exchangeable $\mathrm{Na}^{+}$. Near the heater, exchangeable $\mathrm{Mg}^{2+}$ was higher compared to the reference values and $\mathrm{Na}^{+}$was lower, which, together with a similar shape of the curves, indicates cation exchange. Exchangeable $\mathrm{Ca}^{2+}$, on the other hand, showed an approximately linear increase towards the heater, but due to methodological problems caused by carbonate dissolution, these $\mathrm{Ca}^{2+}$ values are difficult to explain.

In section 50, where an iodide tracer was applied before the experiment, no residual iodide was found. The values were 4000 times less than those reported in section 30 (ENRESA, 2006), 9 years previously. It is concluded that iodide was washed out.

\section{REFERENCES}

Arcos D., Bruno J., Benbow S. \& Takase H. (2000) Behaviour of Bentonite Accessory Minerals during the Thermal Stage. SKB Technical Report TR-00-06. Available at: http://www.skb.com/publications/.

Bernier F., Li X.-L. \& Bastiaens W. (2007) Twenty-five years' geotechnical observation and testing in the Tertiary Boom Clay formation. Géotechnique, 57, 229-237.
Degueldre C. (1994) Colloid Properties in Groundwater from Crystalline Formations. Nagra Technical Report, NTB 92-05, Nagra, Wettingen, Switzerland.

Dohrmann R. \& Kaufhold S. (2009) Three new, quick CEC methods for determining the amounts of exchangeable calcium cations in calcareous clays. Clays and Clay Minerals, 57, 338-352.

Dohrmann R., Olsson S., Kaufhold S. \& Sellin P. (2013) Mineralogical investigations of the first package of the alternative buffer material test - II. Exchangeable cation population rearrangement. Clay Minerals, 48, 215-233.

Dohrmann R. \& Kaufhold S. (2014) Cation exchange and mineral reactions observed in MX 80 buffers samples of the prototype repository in situ experiment in Äspö, Sweden. Clays and Clay Minerals, 62, 357-373.

Dohrmann R. \& Kaufhold S. (2017) Characterisation of the second package of the alternative buffer material experiment (ABM) - II. Exchangeable cation population rearrangement. Clays and Clay Minerals, 65, 104-121.

ENRESA (2006) Full Scale Engineered Barrier Experiment - Updated Final Report 1994-2004. Publication Tecnica, 05-0/2006. Available at: http://www.enresa.es/eng/index/ about-enresa/publications/category/9-institutional.

Fernández A.M. \& Villar M.V. (2010) Geochemical behaviour of a bentonite barrier in the laboratory after up to 8 years of heating and hydration. Applied Geochemistry, 25, 809-824.

Fernández A.M. (2017) Gas and Water Sampling in Different Pipes from the FEBEX In Situ Test at the Grimsel Test Site. Nagra Arbeitsbericht, NAB 16-013. Nagra, Wettingen, Switzerland.

Fernández A.M., Cuevas J. \& Rivas P. (2001) Pore water chemistry of the FEBEX bentonite. Materials Research Society Symposium Proceedings, 663, 573-588.

Fernández A.M., Baeyens B., Bradbury M. \& Rivas P. (2004) Analysis of the porewater chemical composition of a Spanish compacted bentonite used in an engineered barrier. Physics and Chemistry of the Earth, 29, 105-118.

Ferrage E., Lanson B., Sakharov B.A. \& Drits V.A. (2005) Investigation of smectite hydration properties by modeling experimental X-ray diffraction patterns: part I. Montmorillonite hydration properties. American Mineralogist, 90, 1358-1374.

García-Siñeriz J.L., Abós H., Martínez Leon V., De la Rosa C., Mäder U. \& Kober F. (2016) FEBEX DP: Dismantling of Heater 2 at the FEBEX 'In Situ' Test: Description of Operations. Nagra Arbeitsbericht, NAB 16-011. Nagra, Wettingen, Switzerland.

Garralón A., Gómez P., Peña J., Buil B., Turrero M.J., Torres E. \& Sánchez L. (2017) Hydrogeochemical Characterization of the Groundwater in the FEBEX Gallery. Nagra Arbeitsbericht, NAB 16-014. Nagra, Wettingen, Switzerland.

Gugala J. (2015) Final report LUCOEX - WP3. ALC full scale emplacement experiment. EU project LUCOEX, deliverable D3.4. Available at: www.lucoex.eu. 
Huertas F., Fariña P., Farias J., García-Siñeriz J.L., Villar M.V., Fernández A.M., Martin P.L., Elorza F. J., Gens A., Sañchez M., Lloret A., Samper J. \& Martínez M.A. (2006) Full-Scale Engineered Barriers Experiment. Updated Final Report 1994-2004. Publicacion Tecnica ENRESA, Hornachuelos, Spain.

Johannesson L.-E., Börgesson L., Goudarzi R., Sandén T., Gunnarsson D. \& Svemar C. (2007) Prototype repository: a full-scale experiment at Aspö HRL. Physics and Chemistry of the Earth, 32, 58-76.

Karnland O., Olsson S., Dueck A., Birgersson M., Nilsson U., Hernan-Håkansson T., Pedersen K., Nilsson S., Eriksen T.E. \& Rosborg B. (2009) Long Term Test of Buffer Material at the Äspö Hard Rock Laboratory, LOT Project Final Report on the A2 Test Parcel. SKB Report. SKB TR-09-29. Available at: http://www.skb.com/publications/.

Kaufhold S., Pohlmann-Lortz M., Dohrmann R. \& Nüesch R. (2007) About the possible upgrade of bentonite with respect to iodide retention capacity. Applied Clay Science, 35, 39-46.

Kaufhold S., Dohrmann R., Sandén T., Sellin P. \& Svensson D. (2013) Mineralogical investigations of the alternative buffer material test - I. Alteration of bentonites. Clay Minerals, 48, 199-213.

Kaufhold S., Sanders D., Dohrmann R. \& Hassel A.-W. (2015) Fe corrosion in contact with bentonites. Journal of Hazardous Materials, 285, 464-473.

Kaufhold S., Dohrmann R. \& Ufer K. (2016) Interaction of magnesium cations with dioctahedral smectites under HLRW repository conditions. Clays and Clay Minerals, 64, 743-752.

Kaufhold S., Dohrmann R., Götze N. \& Svensson D. (2017) Characterisation of the second parcel of the alternative buffer material (ABM) experiment I. Mineralogical reactions. Clays and Clay Minerals, 65, 27-41.

Lanyon G.W. \& Gaus I. (editors) (2013) Main Outcomes and Review of the FEBEX In Situ Test (GTS) and Mock-Up After 15 Years of Operation. Nagra working report, NAB 13-96. Nagra, Wettingen, Switzerland.

Lanyon G.W. \& Gaus I. (2015) Grimsel Test Site Investigation Phase VI. Main Outcomes and Review of the FEBEX In Situ Test (GTS) and Mock-Up After 15 Years of Operation. Nagra Technical Report NTB 15-04. Nagra, Wettingen, Switzerland.

Lloret A. \& Villar M.V. (2007) Advances on the knowledge of the thermo-hydro-mechanical behaviour of heavily compacted 'FEBEX' bentonite. Physics and Chemistry of the Earth, 32, 701-715.

Martinez V., Abós H. \& García-Siñeriz J.L. (2016) FEBEXe: Final Sensor Data Report (FEBEX 'In Situ' Experiment). Nagra Arbeitsbericht NAB 16-19. Nagra, Wettingen, Switzerland.

Meier L.P. \& Kahr G. (1999) Determination of the cation exchange capacity (CEC) of clay minerals using the complexes of copper (II) ion with triethylenetetramine and tretraethylenepentamine. Clays and Clay Minerals, 47, 386-388.

Müller H.R., Garitte B., Vogt T., Köhler S., Sakaki T., Weber H., Spillmann T., Hertrich M., Becker J.K., Giroud N., Cloet V., Diomidis N. \& Vietor T. (2017) Implementation of the fullscale emplacement (FE) experiment at the Mont Terri rock laboratory (Switzerland). Swiss Journal of Geosciences, 110, $1-20$.

Svemar C., Johannesson L.-E., Grahm P., Svensson D., Kristensson O., Lönnqvist M. \& Nilsson U. (2016) Prototype Repository. Opening and Retrieval of Outer Section of Prototype Repository at Äspö Hard Rock Laboratory. Summary Report, SKB TR-13-22. Available at: http://www.skb.com/publications/.

Svensson D. (2015) Saponite formation in the ABM2 iron-bentonite field experiment at Äspö hard rock laboratory, Sweden. Pp. 168-169 in: Clays in Natural and Engineered Barriers for Radioactive Waste Confinement. Sixth International Meeting, Program \& Abstracts, Brussels, Belgium.

Turrero M.J. \& Cloet V. (editors) (2017) FEBEX-DP Concrete Studies. Nagra Arbeitsbericht NAB 16-018. Nagra, Wettingen, Switzerland.

Ufer K., Stanjek H., Roth G., Dohrmann R., Kleeberg R. \& Kaufhold S. (2008) Quantitative phase analysis of bentonites by the Rietveld method. Clays and Clay Minerals, 56, 272-282.

Villar M.V., Fernández A.M., Rivas P., Lloret A., Daucausse D., Montarges-Pelletier E., Devineau K., Villieras F., Hynková E., Cechova Z., Montenegro L., Samper J., Zheng L., Robinet J.C., Muurinen A., Weber H.P., Börgesson L. \& Sandén T. (2006) FEBEX Post-Mortem Bentonite Analysis. Publicacion Tecnica ENRESA, Hornachuelos, Spain.

Villar M.V. \& Lloret A. (2007) Dismantling of the first section of the FEBEX in situ test: THM laboratory tests on the bentonite blocks retrieved. Physics and Chemistry of the Earth, 32, 716-729.

Villar M.V., Iglesias R.J., Abós H., Martínez V., de la Rosa C., Manchón M.Á. (2016) FEBEX-DP On-Site Analyses Report. Nagra Arbeitsbericht, NAB 16-012. Nagra, Wettingen, Switzerland.

Villar M. (editor) (2017) FEBEX-DP Postmortem THM/ THC Analysis Report. Nagra Arbeitsbericht, NAB 16-017. Nagra, Wettingen, Switzerland.

Wallis I., Idiart A., Dohrmann R. \& Post V. (2015) Geochemical evolution of bentonite clays within the first alternative buffer material test (ABM) - a reactive transport modeling study. Goldschmidt Conference 2015, Prague, Czech Republic, 16-21 August 2015. Abstract 3312.

Wersin P. \& Kober F. (editors) (2016). FEBEX-DP Corrosion Report. Nagra Arbeitsbericht, NAB 16016. Nagra, Wettingen, Switzerland. 